AperTO - Archivio Istituzionale Open Access dell'Università di Torino

Eocene partial melting recorded in peritectic garnets from kyanite-gneiss, Greater Himalayan Sequence, central Nepal

This is a pre print version of the following article:

Original Citation:

Availability:

This version is available http://hdl.handle.net/2318/155642

since 2017-05-11T09:40:35Z

Publisher:

Geological Society, London, Special Publications

Published version:

DOI:10.1144/SP412.1

Terms of use:

Open Access

Anyone can freely access the full text of works made available as "Open Access". Works made available under a Creative Commons license can be used according to the terms and conditions of said license. Use of all other works requires consent of the right holder (author or publisher) if not exempted from copyright protection by the applicable law. 
Geological Society, London, Special Publications Online First

\section{Eocene partial melting recorded in peritectic garnets from kyanite-gneiss, Greater Himalayan Sequence, central Nepal}

Rodolfo Carosi, Chiara Montomoli, Antonio Langone, Alice Turina, Bernardo Cesare, Salvatore laccarino, Luca Fascioli, Dario Visonà, Ausonio Ronchi and Santa Man Rai

Geological Society, London, Special Publications, first published September 9, 2014; doi 10.1144/SP412.1

$\begin{array}{ll}\text { Email alerting } & \text { click here to receive free e-mail alerts when } \\ \text { service } & \text { new articles cite this article } \\ \text { Permission } & \text { click here to seek permission to re-use all or } \\ \text { request } & \text { part of this article } \\ \text { Subscribe } & \text { click here to subscribe to Geological Society, } \\ & \text { Condon, Special Publications or the Lyell } \\ & \text { Collection }\end{array}$

How to cite click here for further information about Online First and how to cite articles

\section{Notes}




\title{
Eocene partial melting recorded in peritectic garnets from kyanite-gneiss, Greater Himalayan Sequence, central Nepal
}

\author{
RODOLFO CAROSI ${ }^{1 *}$, CHIARA MONTOMOLI ${ }^{2,7}$, ANTONIO LANGONE $^{3}$, \\ ALICE TURINA $^{4}$, BERNARDO CESARE ${ }^{4}$, SALVATORE IACCARINO $^{2}$, \\ LUCA FASCIOLI ${ }^{5}$, DARIO VISONÀ ${ }^{4}$, AUSONIO RONCHI ${ }^{5}$ \& SANTA MAN RAI ${ }^{6}$ \\ ${ }^{1}$ Dipartimento di Scienze della Terra, Università di Torino, v. Valperga Caluso, \\ 3510125 Torino, Italy
}

${ }^{2}$ Dipartimento di Scienze della Terra, Università di Pisa, v. S. Maria, 5356126 Pisa, Italy

${ }^{3}$ C.N.R.-Istituto di Geoscienze e Georisorse, UOS Pavia, via Ferrata, 127100 Pavia, Italy

${ }^{4}$ Dipartimento di Geoscienze, Università di Padova, Via Gradenigo, 6 35131, Padova, Italy

${ }^{5}$ Dipartimento di Scienze della Terra, Università di Pavia, Via Ferrata, 1 27100, Pavia, Italy

${ }^{6}$ Department of Geology, Tribuhuvan University, Ghantaghar, Kathmandu, Nepal

${ }^{7}$ C.N.R.-Istituto di Geoscienze e Georisorse, v. Moruzzi, 156124 Pisa, 56100 Pisa, Italy

*Corresponding author (e-mail: rodolfo.carosi@unito.it)

\begin{abstract}
Anatectic melt inclusions (nanogranites and nanotonalites) have been found in garnet of kyanite-gneiss at the bottom of the Greater Himalayan Sequence (GHS) along the Kali Gandaki valley, central Nepal, c. $1 \mathrm{~km}$ structurally above the Main Central Thrust (MCT). In situ $\mathrm{U}-\mathrm{Th}-\mathrm{Pb}$ dating of monazite included in garnets, in the same structural positions as melt inclusions, allowed us to constrain partial melting starting at c. 41-36 Ma. Eocene partial melting occurred during prograde metamorphism in the kyanite stability field (Eo-Himalayan event). Sillimanite-bearing mylonitic foliation wraps around garnets showing a top-to-the-SW sense of shear linked to the MCT ductile activity and to the exhumation of the GHS. These findings highlight the occurrence of an older melting event in the GHS during prograde metamorphism in the kyanite stability field before the more diffuse Miocene melting event.

The growth of prograde garnet and kyanite at 41-6 Ma in the MCT zone, affecting the bottom of the GHS, suggests that inverted metamorphism in the MCT zone and folded isograds in the GHS should be carefully proved with the aid of geochronology, because not all Barrovian minerals grew during the same time span and they grew in different tectonic settings.
\end{abstract}

The Himalayan mountain belt, which developed during the India-Asia collision from c. $55 \mathrm{Ma}$, is regarded as a classic collisional orogen. It is characterized by the impressive continuity over $2500 \mathrm{~km}$ of tectonic units, thrusts and normal faults, as well as large volumes of high-grade metamorphic rocks and granite exposed at the surface. This constitutes an invaluable field laboratory to unravel the tectonic and metamorphic evolution of crystalline units and the mechanisms of exhumation of deep-seated rocks in orogens.

Several first-order tectonic discontinuities have been recognized in the Himalaya. From bottom to top these are the Main Frontal Thrust, the Main Boundary Thrust, the Main Central Thrust (MCT) and the South Tibetan Detachment (STD) System (STDS), respectively (Gansser 1964, 1983; Le Fort 1975; Burchfiel et al. 1992; Hodges 2000; Yin 2006). Among these the MCT and STD bound the Greater Himalayan Sequence (GHS) in between, containing most of the metamorphic rocks of the Himalaya (Burchfiel et al. 1992; Hodges 2000; Mukherjee 2013).

In recent years, more attention has been focused on the internal structure of the GHS where increasing evidence of the occurrence of tectono-metamorphic discontinuities highlights their primary role in the exhumation of the GHS (Goscombe et al. 2006; Carosi et al. 2007, 2010; Imayama et al. 2012; Mukherjee et al. 2012; Montomoli et al. 2013; Larson et al. 2013; Mukherjee, this volume, in prep). Although there are many studies on metamorphism, melt generation and deformation concentrated in the same time span as activity on the MCT and STD (c. 23-17 Ma; Godin et al. 2006), much less data on deformation, metamorphism, melt generation and geochronology in the GHS is available for the large time span (c. 30 myr) between collision at c. $55 \mathrm{Ma}$ and MCT-STD activities. 


\section{R. CAROSI ET AL.}

$\mathrm{U}-\mathrm{Th}-\mathrm{Pb}$ metamorphic ages between 50 and $25 \mathrm{Ma}$ on monazite and zircon have been reported only sporadically in the GHS (Hodges et al. 1996; Coleman 1998; Vance \& Harris 1999; Simpson et al. 2000; Catlos et al. 2001, 2002, 2007; Kohn et al. 2004, 2005; Carosi et al. 2010; Groppo et al. 2010; Corrie \& Kohn 2011; Imayama et al. 2012; Rubatto et al. 2012).

Melt generation and granite emplacement have been related mainly to the exhumation stage of the GHS (Harris \& Massey 1994; Patiño-Douce \& Harris 1998) during the Early Miocene (Yin 2006; Searle 2013). Streule et al. (2010) recognized in the Makalu area two main phases of leucogranite production: (i) the older one from 24 to $21 \mathrm{Ma}$ and (ii) the most recent one, related to the genesis of the cordierite-bearing leucogranite at $c .16 \mathrm{Ma}$.

Very little evidence of partial melting during prograde metamorphism has been reported until now in the southern part of the belt (Godin et al. 2001; Imayama et al. 2012). The GHS of eastern Nepal and Sikkim (India) shows the occurrence of melting at the bottom of the GHS (Barun gneiss) at nearly 33-27 Ma (Imayama et al. 2012; Ferrero et al. 2012; Rubatto et al. 2012).

In this paper, we report old ages of monazite up to 41-36 Ma in the lower part of the kyanitegneiss in the GHS in the Kali Gandaki valley (central Nepal) (Fig. 1) as well as evidence of coeval partial melting as attested by melt inclusions in garnets. Compositional X-ray maps of garnets allow us to better constrain monazite ages and melting within the prograde/retrograde path of the rocks. These new data enable refined tectono-metamorphic evolution of the kyanite-gneiss in central Himalaya and constrain current tectonic models widely accepted for the exhumation of the GHS.

\section{Geological outline}

The main structure of the Himalaya can be divided into a few principal tectonic zones, separated by prominent tectonic discontinuities that can be followed along the entire length of the belt (Gansser 1964; Le Fort 1975; Upreti 1999; Hodges 2000; Yin 2006).

Along a north-south structural transect perpendicular to the belt in Nepal, these principal tectonic zones occur as follows: the Terai, the Siwalik (Sub-Himalayan), the Lesser Himalayan Sequence (LHS), the GHS and the Tethyan Sedimentary Sequence (TSS).

The Terai unit is the northern edge of the alluvial plain of the Ganges and Indus rivers (Indo-Gangetic Plain), the foreland basin of the Himalaya with the most recent alluvial sediments (Upreti 1999).

The Sub-Himalayan unit (Siwalik Group) represents the foreland basin, made up by a Tertiary

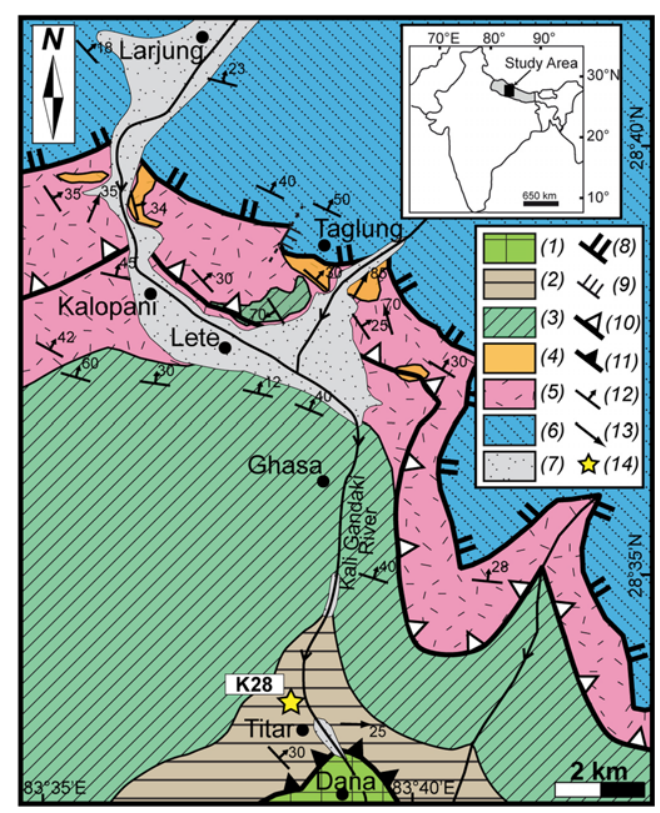

Fig. 1. Geological sketch map of the Kali Gandaki valley (modified after Vannay \& Hodges (1996)) with locations of the studied samples. 1, Lesser Himalaya (quartzite); 2, kyanite-gneiss (GHS); 3, calc-silicate and marble (GHS); 4, metapelite (GHS); 5, orthogneiss (GHS); 6, Tethyan Sedimentary Sequence (TSS); 7, alluvial debris; 8, STD; 9, minor normal fault; 10, Kalopani shear zone; 11, MCT; 12, main foliation; 13, object lineation; 14, studied samples.

molasse in a sedimentary sequence that varies from 2 to $10 \mathrm{~km}$ in thickness (DeCelles et al. 1998; Upreti 1999; White et al. 2002; Szulc et al. 2006).

The LHS is bound at the base by the Main Boundary Thrust (MBT) and at the top by the MCT, which separates it from the overlying GHS. Both these faults show a top-to-the-SW sense of movement. The LHS mainly consists of lower greenschist to lower amphibolite-facies clastic metasedimentary rocks, organized according to a structurally complex system of fold-and-thrust nappes (DeCelles et al. 1998; Hodges 2000) with stratigraphic thickness exceeding $8-10 \mathrm{~km}$, as suggested by palinspastic reconstructions (Schelling 1992). The predominant rock types are impure quartzites and psammitic slates, phyllites and schists, with subordinate impure marbles, metamorphosed mafic rocks and augen orthogneisses (Hodges 2000).

The uppermost tectonic domain to the north is the TSS, tectonically separated from the lower GHS by a system of normal faults and shear zones (STDS) (Burchfiel et al. 1992). It comprises a nearly continuous sequence of upper Palaeozoic to Eocene sediments, which were deposited on the 
northern passive margin of the Indian plate (Gaetani \& Garzanti 1991). The sequence was generally deformed under very low-grade metamorphic conditions, with the highest metamorphic grade corresponding to the greenschist facies, at the base of the sequence in the Cambro-Ordovician rocks affected by the activity of STDS (Crouzet et al. 2007; Antolín et al. 2011; Dunkl et al. 2011).

The metamorphic core of the Himalaya is represented by the GHS, a continuous belt of highgrade metasedimentary and meta-igneous rocks with associated Miocene leucogranites (Carosi et al. 1999; Hodges 2000; Visonà \& Lombardo 2002; Visonà et al. 2012). They range in age from Neoproterozoic to Ordovician, and have been classically divided into three main lithotectonic units (Units 1, 2 and 3) (Searle \& Godin 2003).

The base of the GHS (Unit 1) consists of predominantly clastic metasedimentary rocks, represented by biotite-muscovite gneisses, although mica schists and phyllites, calc-schists, quartzites, paraamphibolites and subordinate impure marbles are also present. In the upper part of the unit concordant leucosomes or discrete leucogranitic dykes and sills are found within migmatitic gneisses (Hodges 2000).

The middle part of the GHS (Unit 2) is characterized by middle to upper amphibolite-facies calcareous rocks. The predominant rock type is banded calc-silicate gneiss; other lithologies include marble, calc-schist, quartz-rich psammitic schist, paraamphibolite and orthoquartzite (Hodges 2000).

Unit 3 is constituted by augen orthogneiss and migmatitic gneiss, with a few metasedimentary rocks (Hodges 2000). These metapelites and calcsilicates become more frequent towards the top of the unit, and have been correlated recently with the Cambro-Ordovician sequences of the TSS (Larson et al. 2010; Searle 2010). This portion of the sequence is intruded by a dense network of leucogranitic dykes and sills, aged between 22 and $12 \mathrm{Ma}$, which show an increase in deformation approaching the STDS, at the contact zone with the TSS (Carosi et al. 2002, 2007).

The Kali Gandaki valley, in central Nepal, is one of the most studied sections of the chain because it offers an excellent exposure of all the tectonic units (Colchen et al. 1986; Vannay \& Hodges 1996; Upreti \& Yoshida 2005). Here the GHS is c. $10 \mathrm{~km}$ thick. It shows a NE-dipping prominent high-grade foliation with $\mathrm{SW}$-verging isoclinal folds (Brown \& Nazarchuk 1993; Godin 2003; Kellett \& Godin 2009; Searle 2010).

In the Kali Gandaki valley, Unit 1 is represented by kyanite-garnet-bearing gneiss and migmatite that lie in the structurally lowest position and Unit 2 consists of diopside-garnet-amphibole-bearing calc-silicate gneiss, while Unit 3 is characterized by migmatitic quartzo-feldspathic sillimanite-bearing schists and calc-silicate gneiss which are intruded by variably strained garnet-tourmaline augen orthogneiss sills (Godin et al. 2001). The high-grade granulitic and migmatitic metasediments of Unit 1 correlate with the Barun Gneiss in the EverestMakalu region (Bordet 1961; Schärer 1984; Brunel \& Kienast 1986; Lombardo et al. 1993; Pognante \& Benna 1993; Groppo et al. 2012). As a whole the Barun gneiss and its laterally equivalent Kangchenjunga Gneiss and Darjeeling Gneiss (Goscombe et al. 2006) form a continuous horizon for at least $200 \mathrm{~km}$ along the Himalayan chain, from eastern Nepal to Sikkim and Bhutan. Recent studies documented very similar Grt-Kfs-Ky-Sil rocks at the easternmost margin of the Himalayan belt, $1000 \mathrm{~km}$ east of the Barun Gneiss type locality (Guilmette et al. 2010), representing a truly significant portion of the metamorphic core of the Himalaya (Groppo et al. 2012).

\section{Petrography and microstructures of kyanite-gneiss}

Thin sections were obtained from samples K-28 collected in the Kali Gandaki valley close to Titar village (N28 $34^{\prime} 13^{\prime \prime}$;E83 $38^{\prime} 20^{\prime \prime}, 1787 \mathrm{~m}$ above sea level) (Fig. 1). The samples come from the kyanitegneiss in the lower part of the GHS (Unit 1) involved in the MCT deformation. Samples K-28 (a, b, c) from the kyanite-gneiss were studied in detail. Single garnets used for remelting experiments were picked up from floating garnet grains at the base of the outcrop.

The mineral assemblage of the gneisses is: quartz + plagioclase + biotite + garnet + kyanite + muscovite + chlorite \pm sillimanite. Accessory minerals are monazite, xenotime, apatite, zircon, tourmaline, rutile, ilmenite and pyrite. Note that rutile occurs only within garnet and kyanite grains, while ilmenite seems the stable matrix Ti-phase.

Samples K-28 (a, b, c) have a porphyroclastic texture with subhedral to anhedral porphyroclasts of Grt and Ky. These porphyroclasts are surrounded by a spaced and anastomosing foliation marked by recrystallization of biotite and muscovite into small and oriented crystals. The portions between cleavage domains identify areas with less deformation characterized by large crystals of biotite, garnet and kyanite, with different orientations with respect to the main foliation.

Both quartz and plagioclase grains show microstructures testifying to the recovery and recrystallization processes. Quartz grains present lobate grain boundaries, elongate subgrain extinctions and are often squarish (chessboard extinction). Plagioclase feldspar shows lobate grain boundaries, 


\section{R. CAROSI ET AL.}

deformation twins and a lack of internal microfractures. Kyanite is often twinned and sometimes shows undulose extinction. Pinning and windows microstructures (Passchier \& Trouw 2005) are observed, indicating Grain Boundary Migration recrystallization at relatively high temperature of deformation. Kinematic indicators, such as kyanite and mica fish (Passchier \& Trouw 2005) and shear bands, point to a top-to-the-SW sense of shear related to the ductile shearing of the MCT.

Due to the overprint of deformation after melting, recognition of microstructures linked to the presence of former melt is a difficult task. However, using the criteria recently reviewed by Holness et al. (2011) and Vernon (2011), we could detect micro-evidence of former melt: (a) corroded quartz grains rimmed by feldspar in Q-domain; (b) tiny films of feldspars with low dihedral angles, interpreted as pseudomorphs of melt filling pores; (c) 'string of beads' microstructures; and (d) nanogranite inclusion within peritectic garnet. Pseudomorphs after melt films around kyanite (Fig. 2a) and garnet indicate that partial melting involved kyanite as part of the mineral assemblage (see next paragraph).

Needles of fibrolitic sillimanite occur rarely within the fractured kyanite, sometimes at the rims of biotite and muscovite in contact with garnet (Fig. 2a) and at the boundary of plagioclase. This is microstructural evidence of the $P-T$ path of the rock crossing the stability field of sillimanite after the main assemblage $\mathrm{Ky}-\mathrm{Bt}-\mathrm{Grt}-$ melt equilibrated (mineral abbreviation according to Whitney \& Evans (2010)).

The mineral assemblage $\mathrm{Qtz}+\mathrm{Pl}+\mathrm{Bt}+\mathrm{Ms} \pm$ Grt \pm Ky characterizes the prograde metamorphism
(Vannay \& Hodges 1996), whereas the growth of sillimanite occurred later during decompression.

\section{Occurrence of nanogranites in garnet}

Melt inclusions trapped in peritectic minerals formed during incongruent melting reactions are a novel tool for the microstructural and microchemical investigation of the genesis of crustal melts (Cesare et al. 2011). When slowly cooled, as in migmatites and granulites, these tiny inclusions crystallize in cryptocrystalline aggregates named 'nanogranite' (Cesare et al. 2009).

Melt inclusions have been discovered in the kyanite-gneiss (K-28) from this study, as well as in most of the garnets collected from the same outcrop.

Garnet crystals range from $3-14 \mathrm{~mm}$ in diameter; those observed in thin sections from sample K-28 are usually smaller than the single garnets collected at the bottom of the rock wall and used for the experiments. Systems of parallel fractures cut garnets at high angle to the main foliation. Biotite overgrowths rim those garnets (Fig. 3a). Most of the analysed garnets contain hundreds of nanogranite inclusions that are grouped in clusters and sometimes show a systematic microstructural distribution. However, garnets free of anatectic melt inclusions have also been observed.

Nanogranite inclusions in garnets are up to $50-60 \mu \mathrm{m}$, but most are $10-20 \mu \mathrm{m}$. Often the inclusions are crossed by thin cracks, (deformation or decrepitation cracks) (Fig. 3b). The shape of nanogranites from the Kali Gandaki valley is more irregular than those reported (Cesare et al. 2011;
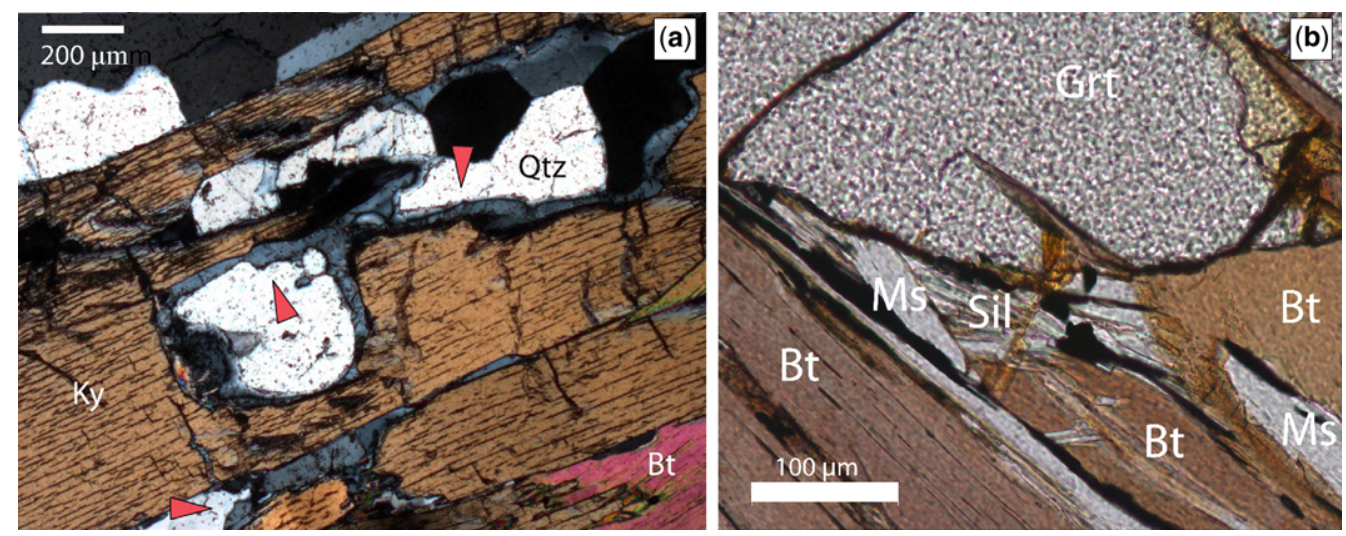

Fig. 2. (a) Thin layers of plagioclase at the boundaries between quartz (Qtz) and kyanite (Ky) constitute pseudomorphs after melt films and indicate the former presence of melt coexisting with kyanite. (b) Needles of acicular sillimanite (Sil; fibrolite) in the Ms-Bt matrix surrounding a garnet (Grt) porphyroblast. 


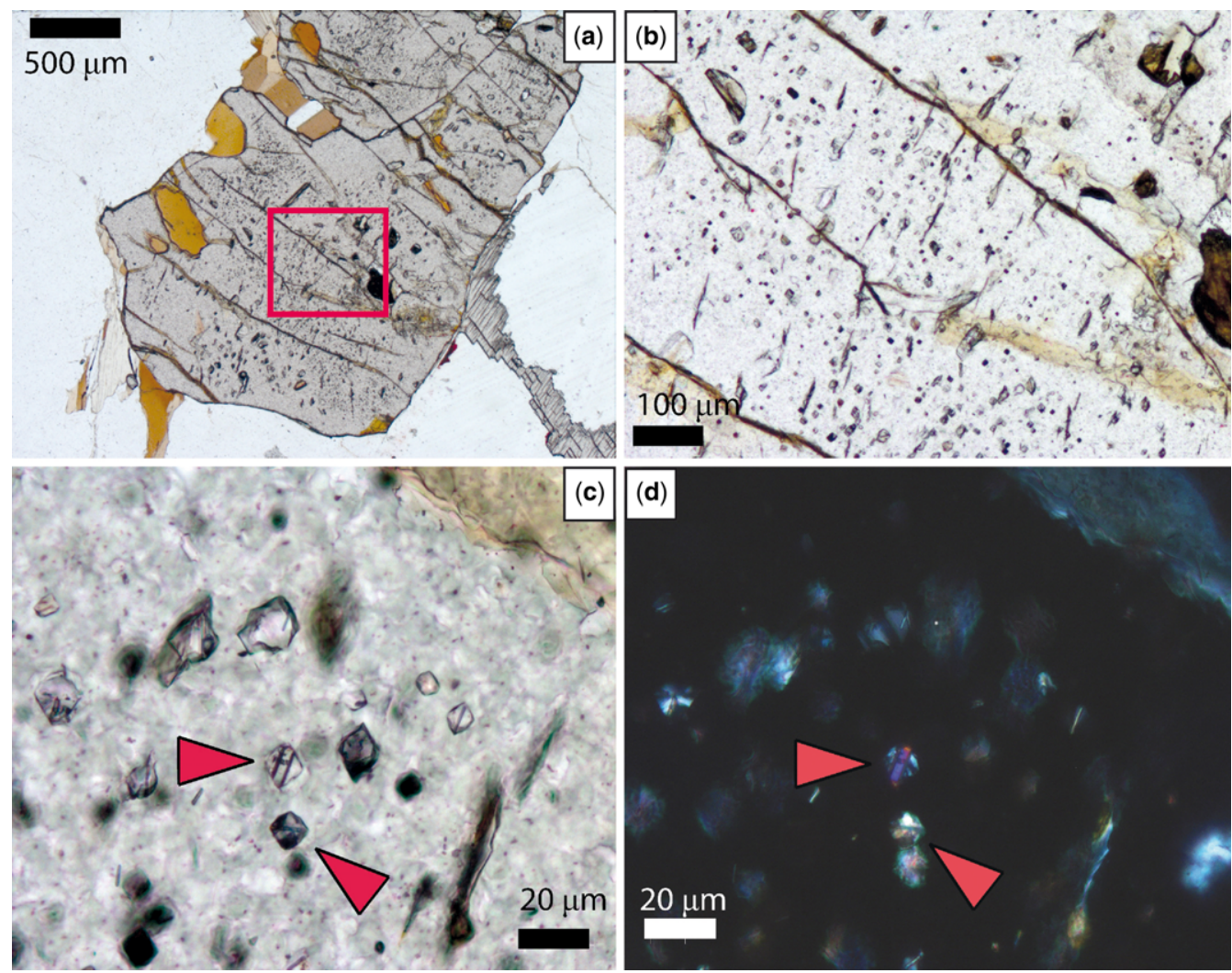

Fig. 3. (a) A porphyroblast of garnet in contact with kyanite, showing abundant inclusions and a set of subparallel, spaced fractures. The outlined box denotes area enlarged in (b). (b) An inclusion-rich area of the garnet. A second set of small fractures, oriented orthogonally to the first, can be observed. (c, d) Close up (plane-polarized light and crossed polars, respectively) of crystallized melt inclusions from the area in (b). Inclusions (arrows) show negative crystal shapes and consist of polycrystalline aggregates.

Ferrero et al. 2012; Bartoli et al. 2013a, b), and negative crystal shapes are less numerous. Cryptocrystalline aggregates of quartz + plagioclase + muscovite + chlorite commonly constitute nanogranites. Chlorite, instead of biotite, within nanogranites, is unusual if compared with those in the literature (Fig. 3c, d).

Tiny inclusions $(1-10 \mu \mathrm{m})$ of ilmenite, rutile, apatite, zircon, monazite, biotite, chlorite, quartz and Ca-rich plagioclase can be found within the clusters of nanogranites. The same mineral phases also occur as solid inclusions in nanogranitefree garnets, or even as trapped minerals in nanogranites (Fig. 4). Given the common association of these accessory phases and nanogranite inclusions, we think that they could have played a role as discontinuities on the surface of the growing garnet, thus promoting the trapping of melt drops. Kyanite never occurs as mineral inclusion within garnet.

\section{Garnet compositional maps and chemistry}

To obtain the chemical composition of the garnets in the studied samples, X-ray maps and chemical profiles were acquired using a CAMECA SX100 electron microprobe (EMP) equipped with five wavelength-dispersive spectrometers, hosted at the Institut für Mineralogie und Kristallchemie of Stuttgart University. Synthetic and natural crystals and pure oxides were used as standards. Beam current and acceleration voltage were $15 \mathrm{nA}$ and $15 \mathrm{kV}$, respectively. Garnet analyses were recalculated on the basis of 24 oxygens using the software MINCALC-V5 (Bernhardt 2010). X-ray concentration maps (for $\mathrm{Mn}, \mathrm{Ca}, \mathrm{Mg}, \mathrm{Fe}$ ) were obtained with a beam current of $50 \mathrm{nA}$ and subsequent computer-aided evaluation. Figure 5a, b presents garnet compositional maps and profiles. Garnet is rich in the almandine component. This mineral is compositionally inhomogeneous and near concentrically 


\section{R. CAROSI ET AL.}
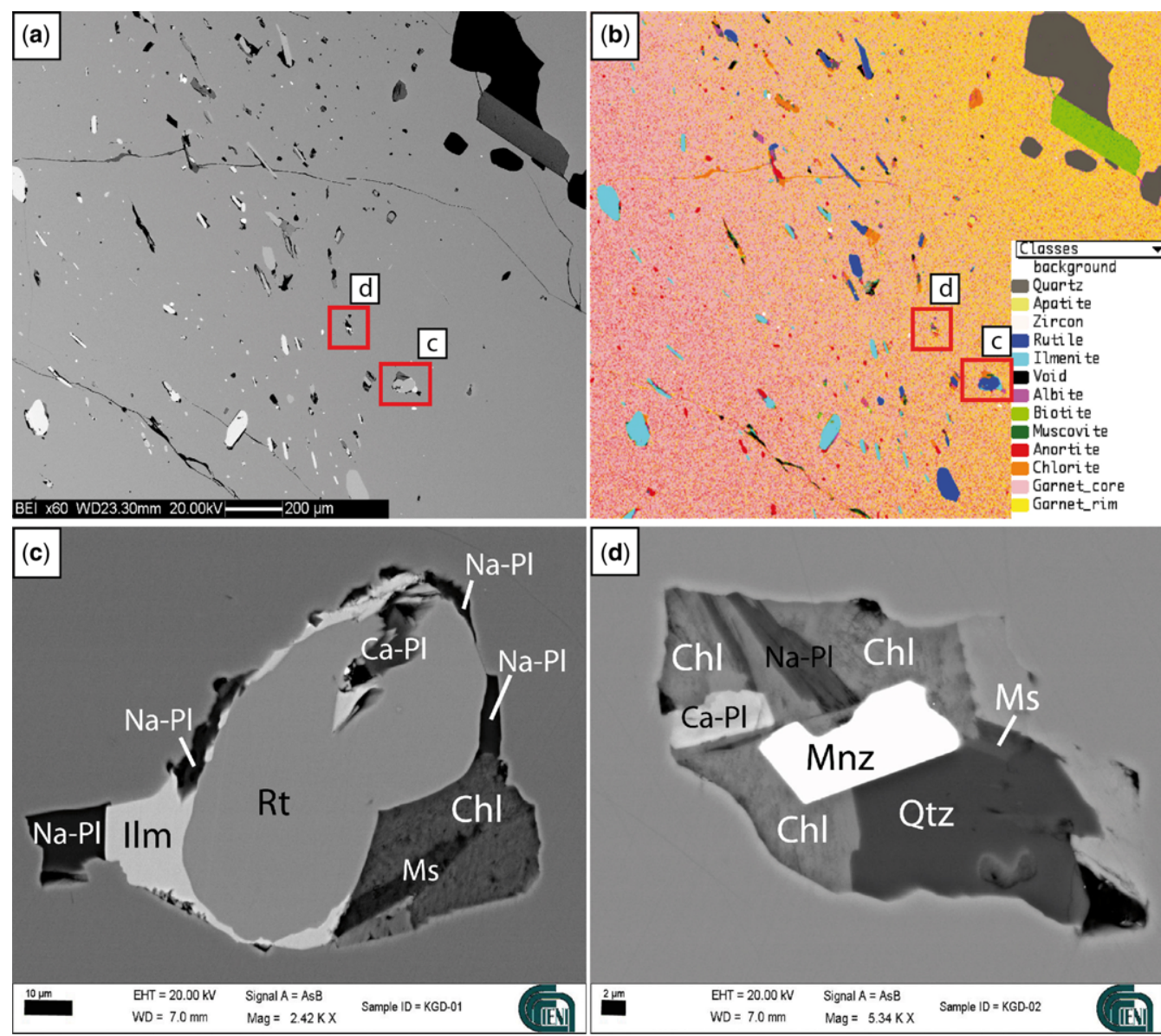

Fig. 4. (a) Backscattered scanning electron microscope (SEM) image of a portion of garnet rich in solid inclusions and nanogranites. The small red boxes indicate the areas enlarged in (c) and (d). (b) The phase reconstruction (based on processing of multispectral image) of the same area as in (a). (c) Crystallized melt inclusion mostly occupied by a trapped rutile partially rimmed by ilmenite. (d) Nanogranite with a trapped crystal of monazite.

zoned (Fig. 5a), with a core where $\mathrm{Mn}$ and $\mathrm{Ca}$ are higher and $\mathrm{Mn}$ and $\mathrm{Fe}$ are lower, which is interpreted as indicative of prograde zoning. According to the compositional profile in Figure $5 b$, the maxima of spessartine and grossular, in the core region, are 9 and $5 \mathrm{~mol} \%$, respectively. These values decrease towards the rims, where a spessartine content of $2.5 \mathrm{~mol} \% \quad\left(X_{\mathrm{Mn}}=0.025\right)$ and a $3.0 \mathrm{~mol} \%\left(X_{\mathrm{Ca}}=0.03\right)$ of grossular are observed. Almandine content increases from core $\left(X_{\mathrm{Fe}}=\right.$ $0.68)$ to $\operatorname{rim}\left(X_{\mathrm{Fe}}=0.76\right)$. The pyrope component increases from core $\left(X_{\mathrm{Mg}}=0.17\right)$ to near rim position $\left(X_{\mathrm{Mg}}=0.22\right)$, where it diminishes towards the outer rims $\left(X_{\mathrm{Mg}}\right.$ up to 0.18$)$. The $\mathrm{Fe} /(\mathrm{Fe}+\mathrm{Mg}$ ) ratio (hereafter referred as Fe\#) decreases from core to near rim (from 0.80 up to 0.77). An upward inflection of Fe\# (up to 0.81) and slight increase in $X_{\mathrm{Mn}}$, coupled with a decrease in $X_{\mathrm{Mg}}(0.18)$ is deduced in the outer rims, suggesting partial retrogression/re-equilibration of the garnet (Kohn \& Spear 2000).

A similar zoning pattern, but higher spessartine (13 $\mathrm{mol} \%)$ and grossular $(13 \mathrm{~mol} \%)$ contents, has been observed in both the large garnets used for the remelting experiments. Their equatorial sections show a characteristic sequence of inclusions that is, from the core to the rim: Ca-rich plagioclase + ilmenite $\rightarrow$ rutile + melt inclusions $\rightarrow$ quartz + muscovite, biotite (larger inclusions). Chlorite is often found in fractures and is probably a secondary mineral of retrograde origin (Fig. 4b). This sequence matches the above-described concentric chemical zoning of the garnet: the borders of nanograniterich areas towards the core correspond to a slight and gradual decrease in $\mathrm{Ca}$ and $\mathrm{Mn}$ and enrichment in $\mathrm{Fe}$ and $\mathrm{Mg}$. 
(a)
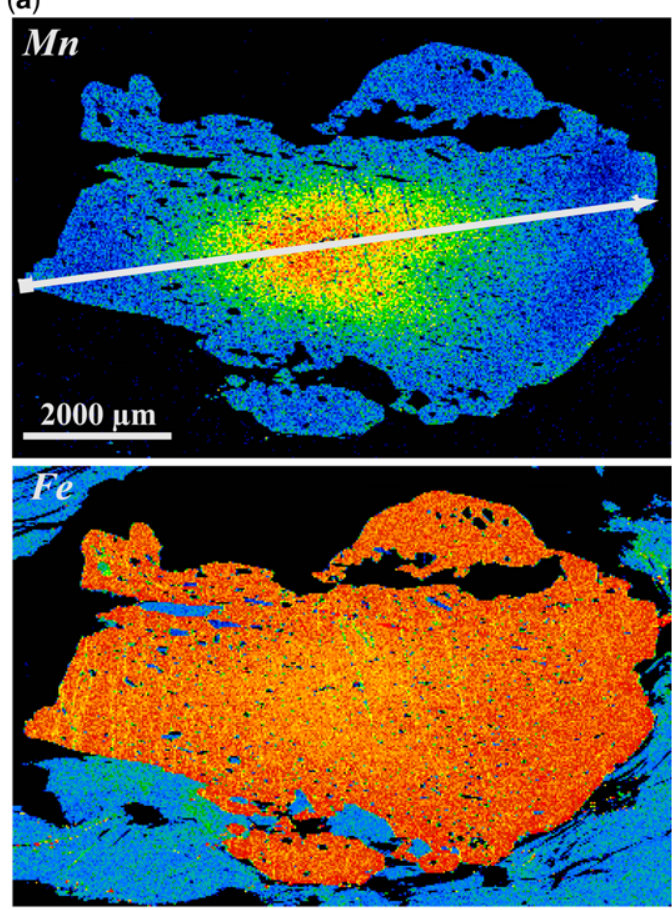

Relative count concentration

(b)

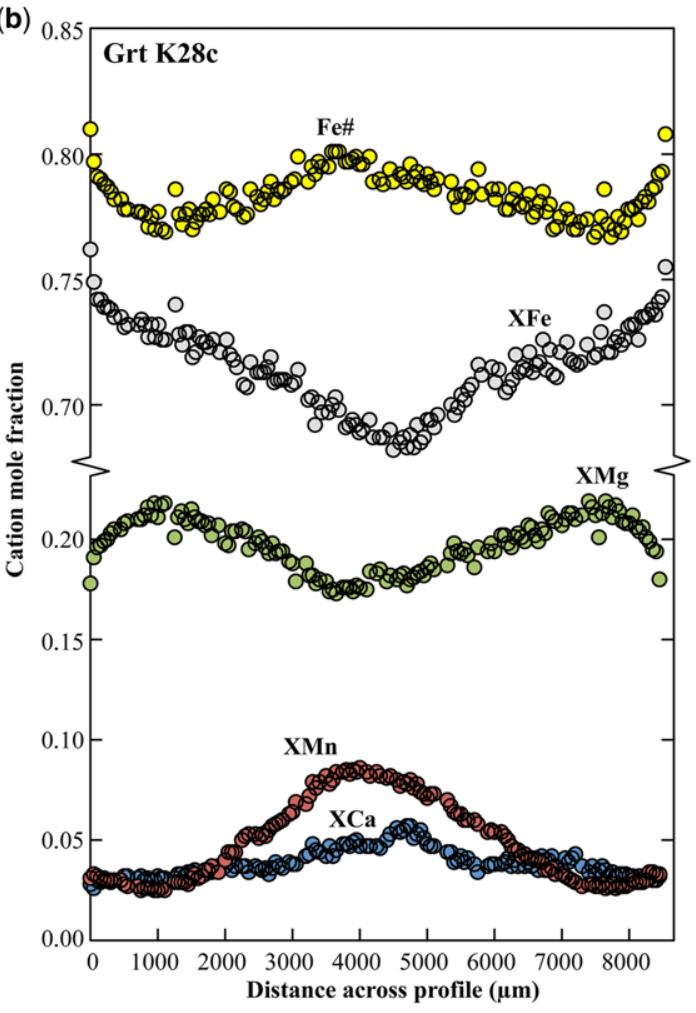

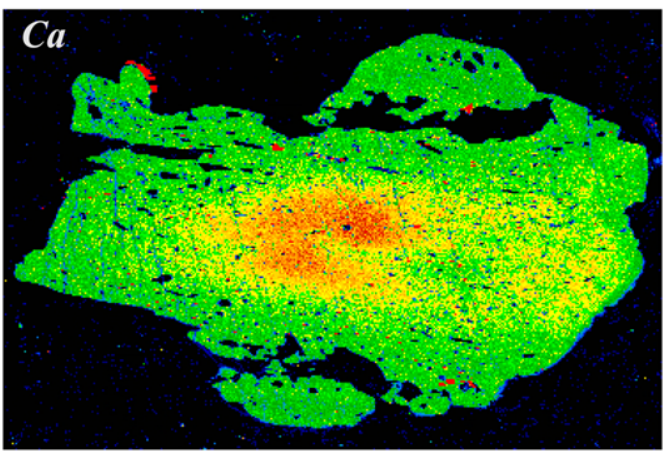

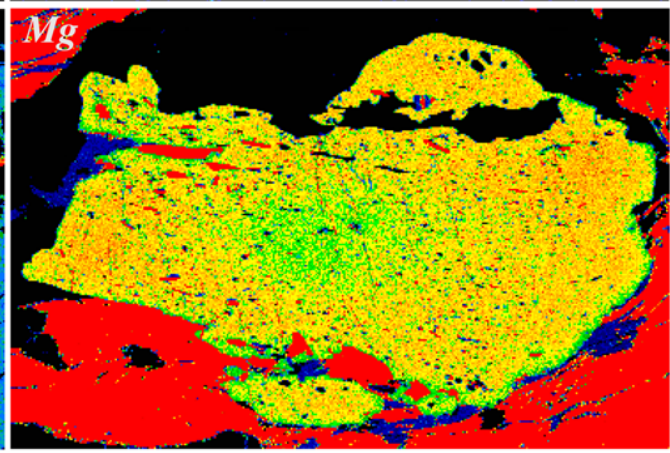

High

Fig. 5. (a) Element concentration map of a garnet porphyroblast. The Mn map shows the exact location of the compositional profile in (b). (b) Garnet compositional line profile from rim to rim in terms of molar fractions. 


\section{R. CAROSI ET AL.}

\section{Microchemical characterization of melt (remelting experiments)}

To obtain the composition of the primary anatectic melts, nanogranites need to be fully re-homogenized, bringing them back to the temperature of trapping or higher. Therefore remelting experiments were performed using a single-stage piston cylinder apparatus at the Laboratory of Experimental Petrology, University of Milan, Italy. Fragments of garnet that contain nanogranites were sealed in a golden capsule with silica powder and then loaded in the apparatus. At the end of the experiments the capsules were mounted in epoxy and uncovered through polishing (Bartoli et al. 2013a, b). Successfully remelted inclusions were then analysed using EMP for major elements, with correction for $\mathrm{Na}$ and $\mathrm{K}$ loss.

We experimented using fragments of garnet crystals coming from the outcrop where sample K-28 was collected. Since the garnets were too large to be loaded into the experimental capsule, they were mounted in epoxy and then cut on the equatorial plane.

In the experimental runs, the main controlling parameter was temperature, which needed to be high enough to cause total rehomogenization, but not chemical interaction with the garnet host. Therefore it is common practice to run more experiments at different temperatures, and to analyse the one that produces total remelting at the lowest temperature. The value of experimental pressure, which does not correspond to the pressure of entrapment, needs only to be high enough to avoid inclusion decrepitation (Bartoli et al. 2013a, b), and was increased in the second run to $12 \mathrm{kbar}$. This value is 2 kbar greater than the pressure estimated by Vannay \& Hodges (1996).

For the first experiment $\left(24 \mathrm{~h}\right.$ duration at $900^{\circ} \mathrm{C}$ and $8 \mathrm{kbar}$ ) we cut thick sections from these exposed planes and fragmented them according to nanogranites-rich clusters. Thus we obtained small wafers of garnet c. $2.5 \mathrm{~mm}$ large and 150-200 $\mu \mathrm{m}$ thick that were loaded into the gold capsule. Up to eight of these garnet wafers, each containing nanogranites, could be loaded in a single capsule. For the second experiment $\left(24 \mathrm{~h}\right.$ at $820^{\circ} \mathrm{C}$ and 12 kbar) we tried a new approach by drilling small cores of garnet using a diamond hollow-core microdrill. We obtained four cylinders of garnet of diameter $2.5 \mathrm{~mm}$ and up to $4 \mathrm{~mm}$ thick. Two were loaded into the capsule.

The experiment at $900{ }^{\circ} \mathrm{C}$ produced overheating of the melt inclusions, and partial decrepitation with some interaction with the host garnet (Bartoli et al. $2013 a, b)$. The experiment run at $820{ }^{\circ} \mathrm{C}$ correctly reproduced the experimental temperature for remelting: here many inclusions appear crystal-free and fully re-homogenized, with negative crystal shape and without cracks that would indicate overpressure and decrepitation (Fig. 5d). The lack of decrepitation is important to preserve the volatile content of the glass.

Interestingly, despite coming from garnets with very similar composition and zoning, the two experiments provided markedly different compositions for re-homogenized glass (Table 1). The glass produced at $900{ }^{\circ} \mathrm{C}$ is granitic (average $\mathrm{SiO}_{2} 71 \mathrm{wt} \%$ ) and slightly peraluminous (average ASI 1.02). $\mathrm{FeO}$ is usually $<2.5 \%$, and average wt $\%$ oxide contents are $\mathrm{Na}_{2} \mathrm{O}=4 \%, \mathrm{~K}_{2} \mathrm{O}=5.2 \%, \mathrm{CaO}=0.4$ and $\mathrm{MgO}=0.2$. The EMP total is $96-97 \%$, but this value could be an overestimation due to the possible loss of volatiles during inclusion decrepitation (Bartoli et al. 2013a, b). Despite the experimental overheating of these nanogranites, the consistent results suggest that the measured granitic composition is reliable.

The inclusions remelted at $820^{\circ} \mathrm{C}$ (Fig. 6), which did not decrepitate and therefore preserved their volatile contents, can be defined nanotonalites: they have an average $\mathrm{SiO}_{2}$ of $66.8 \mathrm{wt} \%$ and are strongly peraluminous (average ASI 1.39). Average wt $\%$ oxide contents are $\mathrm{FeO}=2.78 \%$, $\mathrm{Na}_{2} \mathrm{O}=2.4 \%, \mathrm{~K}_{2} \mathrm{O}=1.2 \%$ and $\mathrm{MgO}=0.45 \%$. A characteristic feature of the chemistry of these melts is an anomalously high $\mathrm{CaO}$ content (average $2.6 \mathrm{wt} \%$ ) with respect to the analysis of other re-homogenized melt inclusions available in the literature. This could be due to a difference in the original chemistry of the protolith, in agreement with experimental evidence (Ferri et al. 2009). The composition of nanotonalites resembles the glass produced by García-Casco et al. (2003) during the experimental fluid-present melting of a natural pelite. Similar Ca-rich silicic melts in equilibrium with Grt, Ky and Bt were also produced by the fluidsaturated melting at $10 \mathrm{kbar}$ and $740{ }^{\circ} \mathrm{C}$ of a Na-free synthetic metapelite (Ferri et al. 2009).

Assuming the fluid content of the melts as $100-$ EMP total, this value is quite high, around $10 \mathrm{wt} \%$ in the inclusions re-homogenized at $820^{\circ} \mathrm{C}$, and supports the fluid-present character of the melting event for this sample.

\section{$\mathrm{U}-\mathrm{Pb}$ geochronology}

\section{Methodology}

Monazite, a light rare earth element phosphate $\left(\mathrm{LREEPO}_{4}\right)$, is ubiquitous in the Himalayan metapelitic rocks (Tobgay et al. 2012; Rubatto et al. 2012). This accessory mineral is a powerful geochronometer (Parrish 1990; Rubatto et al. 2012) and, due to its ability to undergo dissolution/ re-precipitation in response to deformation events 
Table 1. EMP composition of melts from the two remelting experiments 


\section{R. CAROSI ET AL.}
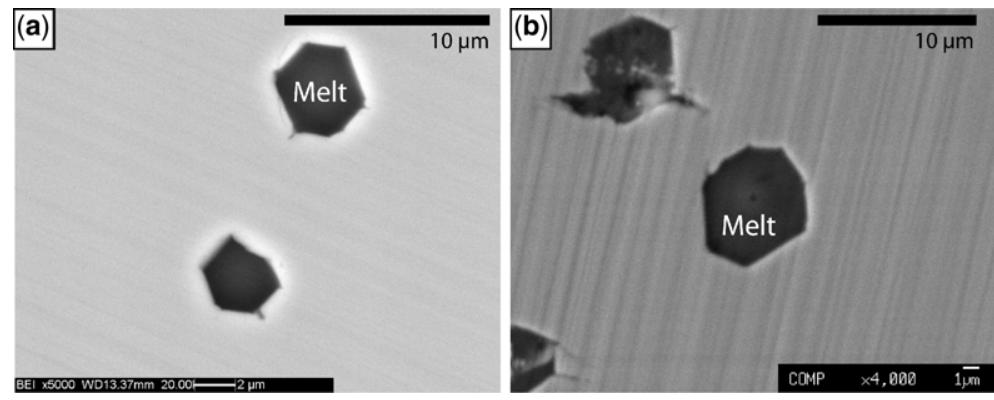

Fig. 6. Example of crystallized inclusions successfully remelted at $820^{\circ} \mathrm{C}$. Inclusions contain a homogeneous melt that has been analysed by electron microprobe.

(Williams \& Jercinovic 2002; Dumond et al. 2008) and/or changes in $P-T$ condition (e.g. Spear 2010; Spear \& Pyle 2002, 2010), offers the possibility to put an absolute time constraint, via in situ geochronology (textural geochronology), on the pressuretemperature-deformation history of the rock (Foster et al. 2000; Williams \& Jercinovic 2002, 2012; Foster \& Parrish 2003; Gibson et al. 2004).

Sample K-28c was selected for U-Th-Pb geochronology. Prior to isotopic analyses, the thin section was imaged by backscattered electrons to locate, characterize (dimensions, microstructural position and internal structures) and select the most suitable monazite crystals.

Monazite grains were analysed in situ by laser ablation-inductively coupled plasma-mass spectrometry (LA-ICP-MS) on $30 \mu \mathrm{m}$-thick sections at the CNR-Istituto di Geoscienze e Georisorse U.O.S. of Pavia (Italy) using an Ar-F 193-nm excimer laser (GeolLas 102 from Micro-Las) coupled with a magnetic sector ICP-MS (Element I from Thermo-Finnigan). The full description of the analytical procedure is reported in Paquette \& Tiepolo (2007) and Tiepolo et al. (2003). Single analyses were performed by one-minute acquisition of the background signal followed by the acquisition of the ablation signal of masses of ${ }^{202} \mathrm{Hg},{ }^{204} \mathrm{Hg}+$ $\mathrm{Pb}),{ }^{206} \mathrm{~Pb},{ }^{207} \mathrm{~Pb},{ }^{208} \mathrm{~Pb},{ }^{232} \mathrm{Th},{ }^{238} \mathrm{U}$, for at least $30 \mathrm{~s}$. ${ }^{202} \mathrm{Hg}$ is acquired in order to correct the isobaric interference of ${ }^{204} \mathrm{Hg}$ on ${ }^{204} \mathrm{~Pb}$ and to evaluate the presence of common lead in the sample. The ${ }^{235} \mathrm{U}$ is calculated from ${ }^{238} \mathrm{U}$ on the basis of the mean ratio ${ }^{238} \mathrm{U} /{ }^{235} \mathrm{U}=137.818$ recently proposed by Hiess et al. (2012). Analytical conditions were $12 \mathrm{~J} \mathrm{~cm}^{-2}$ energy density, $3 \mathrm{~Hz}$ repetition rate and $10 \mu \mathrm{m}$ diameter spot size. Technical and data acquisition parameters are summarized in Appendix A. Time-resolved signals were carefully inspected to verify the presence of perturbations related to inclusions, fractures or mixing of different age domains. Laser-induced elemental fractionation and mass bias were corrected using the matrix-matched external monazite standard (Moacir monazite: Cruz et al. (1996) and Seydoux-Guillaume et al. $(2002 a, b))$ considering the values, re-calibrated for isotopic disequilibrium, reported by Gasquet $e t$ al. (2010). Analytical details and results of Moacir standard are reported in Appendix B. External standards and unknowns were integrated over the same time intervals to ensure the efficient correction of fractionation effects. Data reduction was carried out with the software package GLITTER ${ }^{\circledR}$ (van Achterbergh et al. 2001). In order to have a better estimate of uncertainty affecting the isotopic ratios, the individual uncertainties given by GLITTER ${ }^{\circledR}$, were propagated relative to respective reproducibility of the standard following the procedure as reported in Horstwood et al. (2003). After this error propagation, each analysis is regarded as accurate within quoted errors. Analytical details and results are reported in Table 2. Data processing and graphic representations were made with Isoplot 3.0 software (Ludwig 2003).

\section{Monazite textural, internal features and $U-T h-P b$ data}

Monazite occurs in different textural positions. Generally, monazite grains were found as inclusions within micas, mainly biotite, and quartz; they show irregular shapes and dimensions up to $180+230 \mu \mathrm{m}$. Rarely, monazite crystals were also observed as inclusions within garnet and kyanite porphyroblasts. In these cases, monazite shows sub-rounded shapes and fractures and is smaller with respect to the monazite grains included by the other mineral phases. Backscattered electron (BSE) images revealed that monazite grains commonly show bands, often very narrow, or domains with different BSE properties (Fig. 7a, b). Rarely, monazite appears completely homogeneous or shows irregular inner domains with different BSE properties with respect to the surrounding domains (Fig. 7c, d). 
Table 2. $L A-I C P-M S U-T h-P b$ isotope analyses and calculated ages of monazite from the $K-28 c$ sample

\begin{tabular}{|c|c|c|c|c|c|c|c|c|c|c|c|c|c|c|c|c|c|c|c|c|c|c|c|c|}
\hline \multicolumn{4}{|c|}{27 July 2010, IGG-CNR U.O.S. of Pavia } & \multirow[b]{2}{*}{ Zoning } & \multirow[b]{2}{*}{$\begin{array}{l}{ }^{207} \mathrm{~Pb} / \\
{ }^{206} \mathrm{~Pb}\end{array}$} & \multirow[b]{2}{*}{$1 \sigma \%$} & \multirow[b]{2}{*}{${ }^{207} \mathrm{~Pb} /$} & \multicolumn{3}{|c|}{ Data for Wetherill plot } & \multirow[b]{2}{*}{ Rho } & \multirow[b]{2}{*}{${ }^{208} \mathrm{~Pb} /$} & \multirow[b]{2}{*}{$1 \sigma \%$} & \multicolumn{8}{|c|}{ Ages } & \multirow[b]{2}{*}{$\begin{array}{l}\% \mathrm{U}_{-} \\
\mathrm{Pb} \text { disc }\end{array}$} & \multicolumn{2}{|c|}{ Concordant ages } \\
\hline Identifier & $\begin{array}{c}\text { Monazite } \\
\text { number }\end{array}$ & $\begin{array}{l}\text { Textural } \\
\text { position }\end{array}$ & $\begin{array}{c}\text { Spot } \\
\text { location }\end{array}$ & & & & & $1 \sigma \%$ & $\begin{array}{l}{ }^{206} \mathrm{~Pb} / \\
{ }^{238} \mathrm{U}\end{array}$ & $1 \sigma \%$ & & & & $\begin{array}{l}\overline{{ }^{207} \mathrm{~Pb} /} \\
{ }^{206} \mathrm{~Pb}\end{array}$ & $1 \sigma$ abs & $\begin{array}{l}{ }^{207} \mathrm{~Pb} / \\
{ }^{235} \mathrm{U}\end{array}$ & $1 \sigma$ abs & $\begin{array}{l}{ }^{206} \mathrm{~Pb} / \\
{ }^{238} \mathrm{U}\end{array}$ & $1 \sigma$ abs & $\begin{array}{l}{ }^{208} \mathrm{~Pb} / \\
{ }^{232} \mathrm{Th}\end{array}$ & $1 \sigma \mathrm{abs}$ & & & $2 \sigma \mathrm{abs}$ \\
\hline $7 \mathrm{a} 005$ & 3 & $\mathrm{Bt}$ & core & hom. & 0.05823 & 0.00101 & 0.02299 & 0.00037 & 0.00286 & 0.0 & 0.8 & 0.00089 & 1 & 538 & 9.4 & 2 & 0.4 & 18 & 0.2 & 18 & 0.2 & 20.2 & & \\
\hline J127a006 & 0 & Qtz & rim & bright & 0.05159 & 0.00091 & 0.03695 & 0.00059 & 0.00519 & 0.00007 & 0.8 & 0.00162 & 0.00002 & 267 & 4.7 & 37 & 0.6 & 33 & 0.4 & 33 & 0.5 & 9.4 & & \\
\hline J127a007 & 0 & $\mathrm{Qtz}$ & rim & dark & 0.04679 & 0.00084 & 0.04076 & 0.00068 & 0.00632 & 0.00008 & 0.8 & 0.00198 & 0.00003 & 39 & 0.7 & 41 & 0.7 & 41 & 0.5 & 40 & 0.7 & -0.1 & 40.6 & 1.0 \\
\hline $27 a 008$ & $17+$ & Ky & core & hom. & 0.05112 & 0.00092 & 0.03893 & 0.00065 & 0.00553 & 0.00007 & 0.7 & 0.00160 & 0.00002 & 246 & 4.5 & 39 & 0.6 & 36 & 0.4 & 32 & 0.5 & 8.3 & & \\
\hline J127a009 & $17+$ & Ky & core & hom. & 0.04893 & 0.00092 & 0.04533 & 0.00079 & 0.00672 & 0.00008 & 0.7 & 0.00192 & 0.00003 & 144 & 2.7 & 45 & 0.8 & 43 & 0.5 & 39 & 0.7 & 4.1 & & \\
\hline J127a010 & 18 & Ky & rim & dark & 0.05532 & 0.00098 & 0.03287 & 0.00054 & 0.00431 & 0.00005 & 0.7 & 0.00116 & 0.00002 & 425 & 7.6 & 33 & 0.5 & 28 & 0.3 & 23 & 0.4 & 15.6 & & \\
\hline $7 a 011$ & 18 & $\mathrm{~K}$ & core & bright & 0.04820 & 0.00120 & 0.04614 & 0.00109 & 0.00695 & 0.00009 & 0.6 & 0.00189 & 0.00003 & 109 & 2.7 & 46 & 1.1 & 45 & . & 38 & & 2.5 & & \\
\hline J127a012 & 18 & $\mathrm{~K}$ & rim & dark & 0.05448 & 0.00106 & 0.03156 & 0.00057 & 0.00420 & 0.00005 & 0.7 & 0.00115 & 0.00002 & 391 & 7.6 & 32 & 0.6 & 27 & 0.3 & 23 & 0.4 & 14.4 & & \\
\hline $\mathrm{J} 127 \mathrm{a} 013$ & 17 & B & rim & dark & 0.04733 & 0.00091 & 0.04407 & 0.00079 & 0.00676 & 0.00008 & 0.7 & 0.00199 & 0.00003 & 66 & 1.3 & 44 & 0.8 & 43 & 0.5 & 40 & 0.7 & 0.8 & 43.4 & 1.1 \\
\hline a014 & 25 & B & core & ght & 0.04917 & 0.00095 & 0.04399 & 0.00079 & 0.00649 & 0.00008 & 0.7 & 0.00197 & 0.00003 & 156 & 3.0 & 44 & 0.8 & 42 & 0.5 & 40 & 0. & 4.6 & & \\
\hline J127a015 & 15 & B & rim & bright & 0.05723 & 0.00109 & 0.03308 & 0.00058 & 0.00419 & 0.00005 & 0.7 & 0.00114 & 0.00002 & 500 & 9.6 & 33 & 0.6 & 27 & 0.3 & 23 & 0.4 & 18.4 & & \\
\hline J127a016 & 15 & & core & dark & 0.04780 & 0.00089 & 0.04219 & 0.00073 & 0.00640 & 0.00008 & 0.7 & 0.00188 & 0.00003 & 89 & 1.7 & 42 & 0.7 & 41 & 0.5 & 38 & 0. & 2.0 & 41.1 & 1.0 \\
\hline J127a017 & 15 & B & rim & & 0.05765 & 0.00117 & 0.02954 & 0.00055 & 0.00372 & 0.00005 & 0.7 & 0.00104 & 0.00001 & 516 & 10.4 & 30 & 0.6 & 24 & 0.3 & 21 & 0.2 & 19.0 & & \\
\hline J127a018 & 36 & $\mathrm{t}$ & core & hom & 0.05249 & 0.00104 & 0.03499 & 0.00064 & 0.00484 & 0.00006 & 0.7 & 0.00147 & 0.00002 & 307 & 6.1 & 35 & 0.6 & 31 & 0.4 & 30 & 0.4 & 10.9 & & \\
\hline 019 & $32+$ & t7 & & bright & 0.04772 & 0.00124 & 0.03903 & 0.00096 & 0.00593 & 0.00008 & 0.5 & 0.00183 & 0.00003 & 85 & 2. & d & 1 & . & & 37 & & 2.0 & 38.1 & 1.0 \\
\hline J127a020 & $32+$ & Qtz & rim & dark & 0.05534 & 0.00111 & 0.02477 & 0.00046 & 0.00325 & 0.00004 & 0.7 & 0.00090 & 0.00001 & 426 & 8.5 & 25 & 0.5 & 21 & 0.3 & 18 & 0.2 & 15.8 & & \\
\hline $\mathrm{J} 127 \mathrm{a} 021$ & 31 & Ms & core & & 0.04844 & 0.00091 & 0.04208 & 0.00073 & 0.00630 & 0.00008 & 0.7 & 0.00192 & 0.00003 & 121 & 2.3 & 42 & 0.7 & 40 & 0.5 & 39 & 0.7 & 3.3 & & \\
\hline 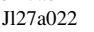 & 29 & & & & 1 & 0.00097 & 0.04489 & 0.00079 & 0.00638 & 0.00008 & 0.7 & 0.00190 & 0.00003 & 241 & 46 & . & & 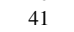 & & & & 8.1 & & \\
\hline $\mathrm{J} 127 \mathrm{a} 023$ & 45 & $\mathrm{~B}$ & rim & & 0.04755 & 0.00087 & 0.03760 & 0.00063 & 0.00573 & 0.00008 & 0.8 & 0.00175 & 0.00002 & 77 & 1.4 & 37 & 0.6 & 37 & 0.5 & 35 & 0. & 1.7 & 36.8 & 0 \\
\hline a024 & 45 & & core & & 4868 & 0.00092 & 0.04380 & 0.00076 & 0.00653 & 0.00008 & 0.7 & 0.00195 & 0.00003 & 132 & 2.5 & 44 & & 42 & & 30 & & 3.6 & & \\
\hline$\pi_{2}$ & 50 & & & ht & 0.04704 & 0.00109 & 0.04129 & 0.00090 & 0.00636 & 0.00008 & 0.6 & 0.00188 & 0.00003 & 51 & 1. & 4 & & 4 & & 38 & & 0.5 & 40.9 & 1.0 \\
\hline J127a028 & 50 & B & rim & (5) & 0.04861 & 0.00101 & 0.03656 & 0.00071 & 0.00546 & 0.00007 & 0.6 & 0.00162 & 0.00002 & 129 & 2.7 & 36 & 0.7 & 35 & 0.4 & 33 & 0. & 3.7 & & \\
\hline 1007 & 52 & & & & & 0.00127 & 0.04269 & 0.00111 & 0.00660 & 0.00009 & 0.5 & 0.00199 & 0.00003 & 42 & 11 & 42 & 1 & 42 & & 4 & 0 & 0.1 & 42.4 & 1.1 \\
\hline & 52 & & & & 0.05981 & 0.00130 & 0.02855 & 0.00058 & 0.00346 & 0.00005 & 0.6 & & 0.00 & 91 & 13.0 & & & & & 20 & & 22.1 & & \\
\hline J127a031 & $61+$ & $\mathrm{Chl}$ & core & & 0.04715 & 0.00090 & 0.04005 & 0.00071 & 0.00616 & 0.00008 & 0.7 & 0.00171 & 0.00002 & 57 & 1.1 & 40 & 0. & 40 & 0. & 35 & 0. & 0.7 & 39.6 & 1.0 \\
\hline 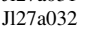 & $61+2$ & Grt & & & & 0.00118 & 0.03656 & 0.00087 & 0.00567 & 0.00008 & 0.6 & 0.00 & 0.00 & 36 & 0 & 36 & 0 & 36 & & 33 & 0 & 0.0 & 36.4 & 1.0 \\
\hline $\mathrm{J} 127 \mathrm{a} 033$ & $61+$ & G & & & 0.05723 & 0.00158 & 0.04136 & 0.00108 & 0.00524 & & 0.5 & 0.00144 & & & 13. & & & & & 29 & & 18.1 & & \\
\hline J127a034 & 62 & $\mathrm{~B}$ & rim & & 0.05008 & 0.00100 & 0.02278 & 0.00042 & 0.00330 & & 0.7 & 0.00093 & 0.00 & 19 & 4. & 2 & 0.4 & 21 & 0.3 & 19 & 0.2 & 7.1 & & \\
\hline$\pi / 2$ & 6 & $\mathrm{Bt}$ & core & band. & 0.047 & 0.00110 & 0.04311 & 0.00094 & 0.00659 & 0.00009 & 0.6 & 0.00 & 0.00 & 73 & 1. & 4 & 0. & 42 & 0. & 41 & 0. & 1.2 & 42.3 & 1.1 \\
\hline J127a036 & 60 & B & & & 0.04828 & 0.00086 & 0.04086 & 0.00067 & & & 0.8 & & & & & & & & & & & 3.0 & & \\
\hline J127a037 & 5 & $\mathrm{Dt}$ & & & & 0.00089 & 0.04243 & 0.00068 & 0.00609 & & 0.8 & & & 21 & 3. & 42 & 0. & 39 & 0. & 36 & 0. & 7.2 & & \\
\hline $\mathrm{J} 127 \mathrm{a} 0$ & $75+$ & Qtz & & bright & 0.04653 & 0.00121 & 0.02093 & 0.00052 & 0.00326 & 0.00004 & 0.5 & 0.00093 & 0.00 & 2 & 0. & 21 & 0. & 21 & 0.3 & 19 & 0. & 0.2 & 21.0 & 0.6 \\
\hline 039 & $75+3$ & $\mathrm{Qtz}$ & ril & & 5134 & 0.00110 & & 043 & & & 0.7 & & & 23 & 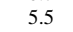 & 22 & & 20 & & & & 9.6 & & \\
\hline & $68+$ & Qtz & & & & 0.00109 & & 0.00090 & 0.00647 & & 0.7 & & & 38 & 7.8 & 48 & 0.9 & 42 & 0.5 & 40 & 0. & 13.6 & & \\
\hline $\mathrm{J} 127 \mathrm{a} 041$ & $68+$ & $\mathrm{Qtz}$ & rim & & 0.04823 & 0.00116 & 0.03534 & 0.00080 & 0.00532 & 0.00007 & 0.6 & 0.00172 & 0.00 & 111 & 2.7 & 35 & 0 & 34 & 0.5 & 35 & 0.6 & 3.0 & & \\
\hline & 75 & $\mathrm{~B}$ & core & & 4647 & & & & & & 0.5 & & & 22 & 0. & 4 & 1. & 42 & & 41 & & -1.0 & 42.0 & \\
\hline & 75 & B & & & & & & & & & 0.4 & & & 43 & 1. & 4. & 1. & 45 & 0. & 41 & 0. & 0.0 & 44.9 & 1.3 \\
\hline $\mathrm{J} 127 \mathrm{a} 044$ & 60 & $\mathrm{Bt}$ & rim & bright & 0.04707 & 0.00087 & 0.04186 & 0.00071 & 0.00645 & 0.00008 & 0.7 & 0.00188 & 0.00 & 53 & 1.0 & 42 & 0.7 & 41 & 0.5 & 38 & 0.7 & 0.5 & 41.4 & 1.0 \\
\hline & 56 & $\mathrm{Bt}$ & core & da & & & & & & & 0.6 & & & 78 & 1. & 42 & 0.9 & 42 & 0. & 40 & 0.1 & 1.4 & 41.8 & 1.0 \\
\hline $\mathrm{J} 127 \mathrm{a} 046$ & 56 & $\mathrm{Bt}$ & rim & dark & 0.05383 & 0.00109 & 0.04433 & 0.00084 & 0.00597 & 0.00008 & 0.7 & 0.00180 & 0.00003 & 364 & 7.4 & 44 & 0.8 & 38 & 0.5 & 36 & 0.7 & 12.9 & & \\
\hline
\end{tabular}




\section{R. CAROSI ET AL.}

Forty in situ $\mathrm{U}-\mathrm{Th}-\mathrm{Pb}$ analyses were carried out on monazite grains in different textural positions (Table 2): within quartz (four grains) and muscovite (one grain) along the foliation planes, and included in garnet (two grains), kyanite (two grains), biotite (13 grains) and chlorite (one grain). Fifteen analyses yielded $\mathrm{U}-\mathrm{Pb}$ concordant data ranging from 45 to $21 \mathrm{Ma}$, defining two major clusters at about 41 and $36 \mathrm{Ma}$ (Fig. 8).

The $\mathrm{U}-\mathrm{Pb}$ analyses of monazite included in garnet and kyanite porphyroclasts did not yield concordant data, except for a single value, at about $36 \mathrm{Ma}$, obtained from a small monazite grain $(18+10 \mu \mathrm{m})$ included in a garnet rim (Fig. 8). All these monazite grains are fractured or located near fractures connecting the grains, or portions of them, with the matrix. Fractures and cracks may promote fluid percolation inducing $\mathrm{U}-\mathrm{Th}-\mathrm{Pb}$ resetting (Montel et al. 2000; Martin et al. 2007; Langone et al. 2011). Interestingly, we have observed that garnet and kyanite appear intensely deformed (i.e. fractures, kink bands and/or folds) as a result of stress partitioning around porphyroblasts during deformation (Kenkmann \& Dresen 1998).
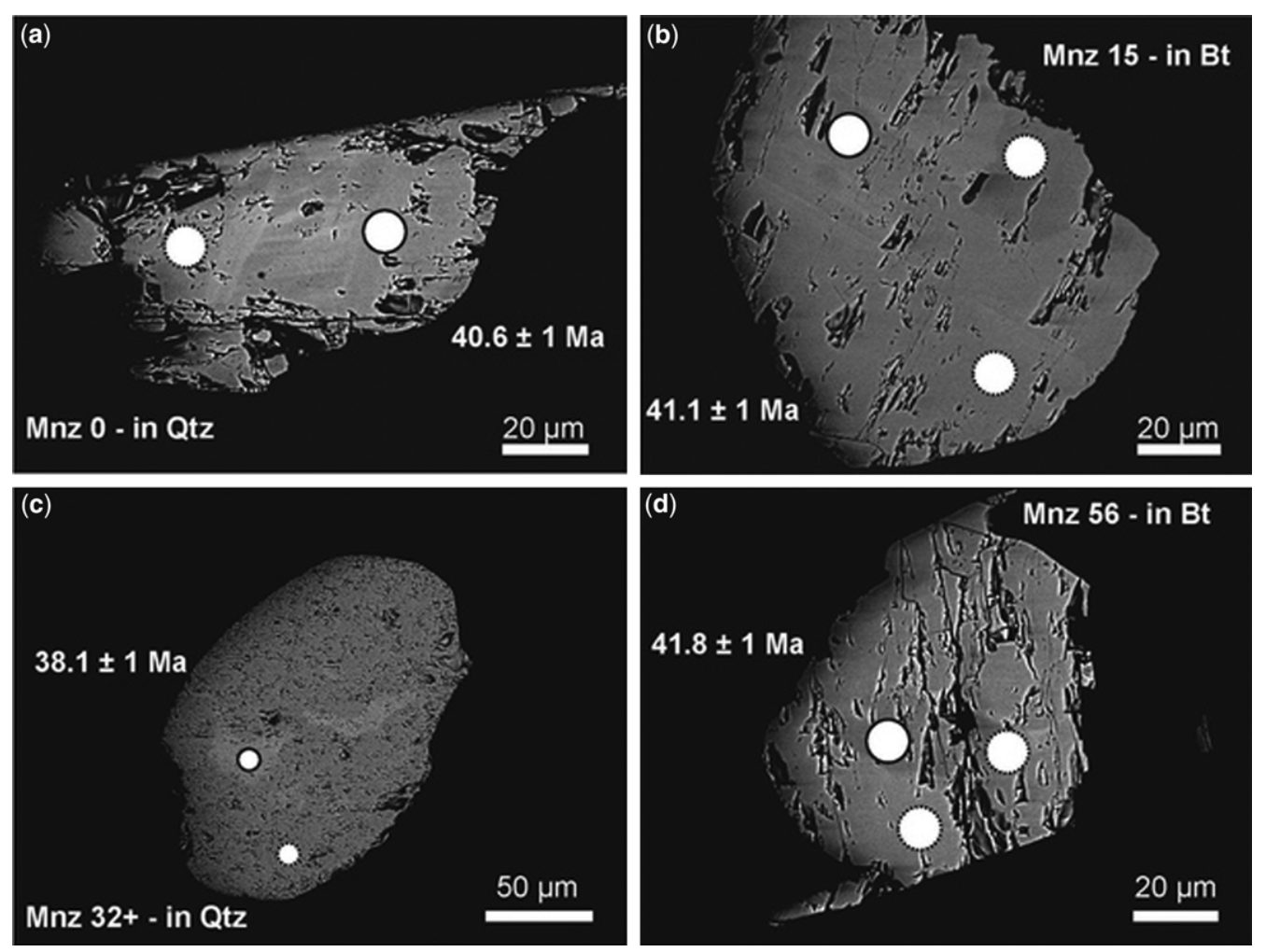

Fig. 7. Backscattered-electron images at high magnification showing monazite shapes and internal features. The white circles indicate locations of the analytical spots providing concordant, continuous contour line and discordant, dashed contour line, $\mathrm{U}-\mathrm{Pb}$ data. 


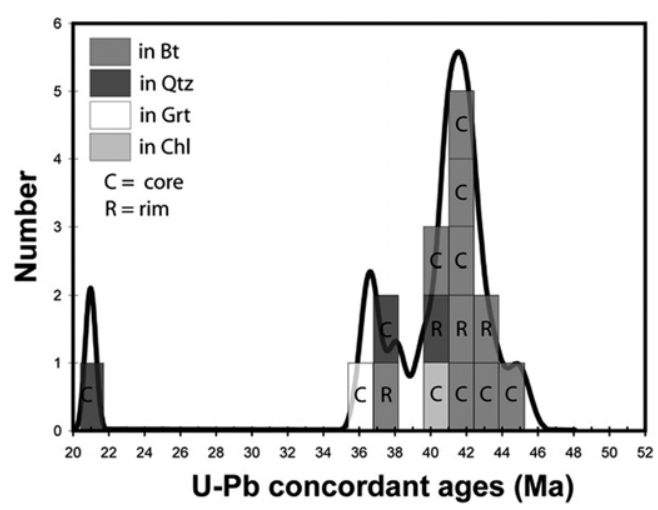

Fig. 8. Probability density plot of monazite concordant data.

pervasive top-to-the-SW shearing linked to Main Central Thrust Zone (MCTZ) activity involving both the upper portion of the LHS and the lowermost part of the GHS. The microstructural position of melt inclusions in the garnets, together with the variation of the chemical composition of garnet, constrained by X-ray maps, allows the constraint of the timing of anatexis during the prograde part of the metamorphism, in the stability field of kyanite.

Remelting experiments were successfully conducted at $820^{\circ} \mathrm{C}$. This temperature is much higher than those obtained by geothermometric calculations on mineral rims used to obtain pressure $(P)$-temperature $(T)$ data in the same rocks by Vannay \& Hodges (1996), which do not exceed $650-700{ }^{\circ} \mathrm{C}$ (Fig. 9). Note, however, that the $P-T$ path of Figure 9 does not enter in the sillimanite stability field, whereas the studied rocks show sillimanite growth after kyanite. They are also higher than the temperatures $\left(675-775^{\circ} \mathrm{C}\right)$ at which García-Casco et al. (2003) experimentally obtained peraluminous tonalitic melts. Note, however, that in the latter experiments staurolite is part of the stable assemblage, whereas it is not observed in sample K-28. Although in other studies (Bartoli et al. 2013a, b) the experimental temperature of successful remelting of nanogranites agrees well with independently (petrologically or geochemically) constrained temperature conditions for anatexis, in this study we cannot exclude that for kinetic reasons the complete remelting of nanotonalites required temperatures in excess of the trapping values. The quantitative evaluation of $P-T$ conditions of anatexis in sample $\mathrm{K}-28$ is beyond the scope of this research.

In situ $\mathrm{U}-\mathrm{Th}-\mathrm{Pb}$ geochronology on monazite in the same microstructural position as the nanogranites (further confirmed by microchemical zoning in garnet) generates information of the timing of their entrapment at c. 41-36 Ma.

Partial melting at $31 \mathrm{Ma}$ in the lower section of the GHS in the Arun valley, eastern Nepal, has

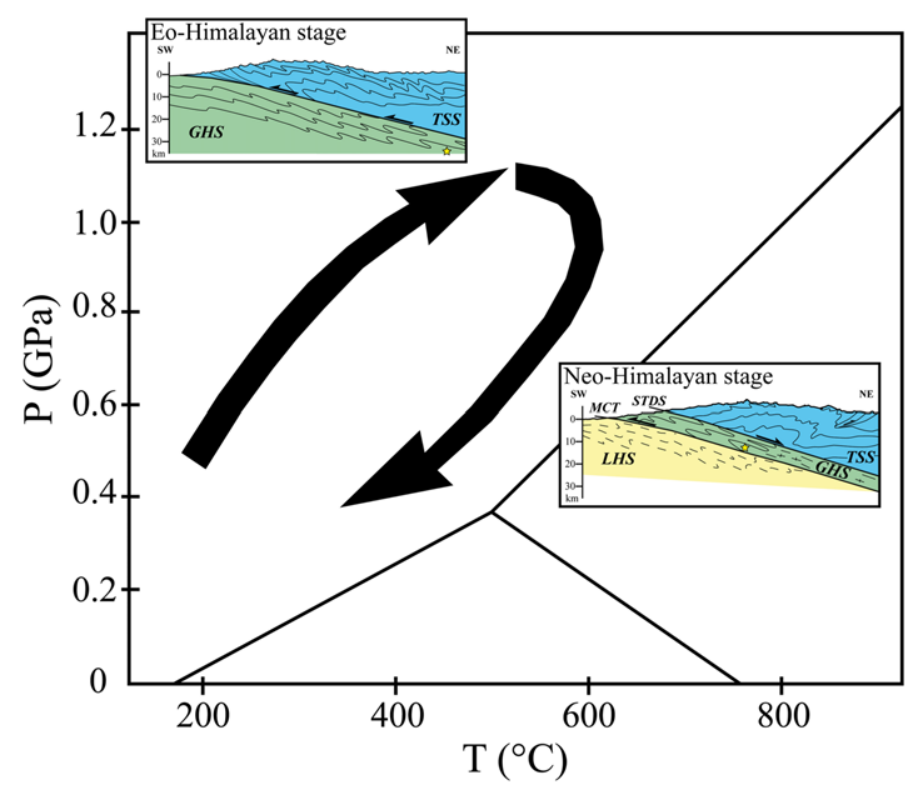

Fig. 9. $P-T-t$ path for the lower GHS-MCT zone as proposed by Vannay \& Hodges (1996). Burial of the GHS is attributed to the Eo-Himalayan stage and decompression and exhumation to the Neo-Himalayan stage. 


\section{R. CAROSI ET AL.}

been attributed by Groppo et al. (2010) to partial melting before MCTZ activity.

In central and eastern Nepal, partial melting, recorded by melt inclusions included within garnets, occurred during prograde metamorphism in the kyanite stability field in relation to increasing $P$ and $T$ due to underthrusting of the GHS following continental collision (Fig. 9).

The occurrence of nanotonalite melts with high Ca composition fits well with the Ca-rich melts occurring in eastern Himalaya (Zeng et al. 2012) and in southern Tibetan gneiss domes (King et al. 2011) developed under fluid-assisted partial melting at higher pressure conditions $(>8 \mathrm{kbar})$ without the contribution of muscovite (Patiño-Douce \& Harris 1998).

The well-known and widespread occurrence of partial melting in the GHS, responsible for the generation of Miocene leucogranites, attributed to the exhumation stage during Lower Miocene by activation of MCTZ and STDS, has been put in relation to decompression (Harris \& Massey 1994; Hodges 2000; Godin et al. 2001; Searle 2013).

This is also in agreement with the finding of several melting stages found by Imayama et al. (2012) and Rubatto et al. (2012) in eastern Nepal. In this framework relics of Oligocene melts are not limited to southern Tibetan gneiss domes but they have been recorded also within the GHS in the frontal part of the belt.

This earlier melting has been interpreted to have triggered the initiation of the channel flow (Beaumont et al. 2001; Mukherjee \& Koyi 2010a, b; King et al. 2011) whereas the Miocene melting testified by the huge amount of high Himalayan granites (Visonà \& Lombardo 2002; Visonà et al. 2012) has been related to the general exhumation stage of the GHS (Harris \& Massey 1994; Hodges 2000).

Monazite ages, related to nanogranites in garnets, at 41-36 Ma (this work) and at 31$28 \mathrm{Ma}$ (Groppo et al. 2010; Imayama et al. 2012; Rubatto et al. 2012) in central and eastern Nepal, respectively, point to a quite larger time span for the occurrence of prograde partial melting in the GHS.

It is worth noting that younger ages of garnets have been reported in the MCTZ in other sections of the belt (i.e. central Nepal: Catlos et al. (2001); Bhutan: Tobgay et al. (2012); western and central Nepal: Montomoli et al. (2013) and Larson et al. (2013)). Moreover younger ages have been attributed to a different tectonic setting, that is, retrograde metamorphism during exhumation. The new data show that the garnets in the same level inside the MCTZ do not define a unique retrograde metamorphic isograd because they show different ages and their growth is related to both prograde and retrograde metamorphic processes.
The occurrence of top-to-the-SW shear zones recently recognized in the GHS (Carosi et al. 2010; Montomoli et al. 2013; Larson et al. 2013) influenced the metamorphic history of the tectonic unit and the path of the rocks within it and different slices underwent prograde and retrograde metamorphism at different times. Connecting the metamorphic isograds in the upper part with the ones in the lower part of the GHS could be misleading without an accurate check of the timing of metamorphism. The new data in the Kali Gandaki valley do not confirm the occurrence of simply folded isograds proposed for the whole GHS by Searle \& Szluc (2005) and Searle (2010).

The data do not exclude, however, the occurrence of an earlier hot channel active soon after the collisional stage but before MCTZ-STDS activity, even if, as suggested by Prince et al. (2001) and King et al. (2011), the melt volume started to be enough to lower the viscosity required for crustal flow only after $28 \mathrm{Ma}$ as indicated by the wide occurrence of granites.

Different mechanisms of exhumation have been proposed by Carosi et al. (2010, 2013), Imayama et al. (2012) and Montomoli et al. (2013, 2014) involving the downward and southward progressive migration of ductile shearing within the GHS, allowing the progressive exhumation of crustal slices of the GHS. In this framework the occurrence of folded isograds within the whole GHS, as postulated by the ductile extrusion and channel flow models, is not confirmed.

The interpretation based only on the simple occurrence of minerals in specimens and thin sections at the bottom and at the top of the GHS is not enough to demonstrate the occurrence of folded isograds. The same applies to the mapping of the inverted metamorphism so that mapping isograds in the field and thin sections can result only in an 'apparent' inverted metamorphism.

\section{Conclusion}

Melts entrapped in garnets during prograde metamorphism in the kyanite stability field have been documented in the kyanite-gneiss at the base of the GHS in the Kali Gandaki valley. In situ $\mathrm{U}-\mathrm{Th}-\mathrm{Pb}$ monazite geochronology constrains their entrapment at 41-36 Ma. Subsequent deformation happened in the sillimanite stability field during decompression and top-to-the-SW shearing linked to the MCT activity.

The composition of Ca-rich melts is in agreement with the occurrence of similar melts found in the Namche Barwa syntaxis and in the southern Tibetan gneiss domes (King et al. 2011; Zeng et al. 2012) produced by muscovite-absent melting 
under high pressure conditions. This first stage of melting was followed by the widespread occurrence of younger melts producing the well-known high Himalayan Miocene leucogranites during the overall decompression of the GHS.

Monazite ages, related to nanogranites in garnets, at 41-36 Ma in the Kali Gandaki valley and at 31-28 Ma in central and eastern Nepal, point to a quite larger time span for the occurrence of melting during prograde metamorphism in the GHS.

Garnets showing both prograde growth at $41-$ $36 \mathrm{Ma}$ and growth in decompression suggest that the explanation of inverted Barrovian isograds in the MCT zone is not straightforward and should be carefully constrained with the aid of in situ geochronology.

The authors are grateful to Prof. H.-J. Massonne (Stuttgart University) for help with laboratory facilities and $\mathrm{Dr}$ T. Theye (Stuttgart University) for invaluable support with electron probe microanalysis (EPMA). Research was funded by PRIN 2010-2011 (R. Carosi, B. Cesare and C. Montomoli). Thanks also go to Prof. S. Poli (Università di Milano) and Dr O. Bartoli for help with melting experiments and to two anonymous referees for their helpful comments. Finally, the authors warmly thank Angharad Hills and Rick Law for support from the Geological Society of London and Soumyajit Mukherjee for editorial handling of the manuscript.

Appendix A. Synthesis of the LA-ICP-MS technical and data acquisition parameters

\begin{tabular}{|c|c|}
\hline \multicolumn{2}{|c|}{$\begin{array}{l}\text { Inductively coupled-plasma mass spectrometry } \\
\text { (ICP-MS) }\end{array}$} \\
\hline Model & $\begin{array}{l}\text { Element I, } \\
\text { ThermoFinningan Mat }\end{array}$ \\
\hline Type & $\begin{array}{l}\text { Single-collector } \\
\text { double-focusing } \\
\text { magnetic sector field }\end{array}$ \\
\hline ICP torch & $\begin{array}{l}\text { Capacitive decoupling } \\
\text { CD-2 }\end{array}$ \\
\hline RF power & $1200 \mathrm{~W}$ \\
\hline \multicolumn{2}{|l|}{ Gas flow: } \\
\hline cooling & $13.51 \mathrm{~min}^{-1}$ \\
\hline auxiliary & $1.51 \mathrm{~min}^{-1}$ \\
\hline Carrier I (Ar) & $1.01 \mathrm{~min}^{-1}$ \\
\hline Carrier II (He) & $1.01 \mathrm{~min}^{-1}$ \\
\hline \multicolumn{2}{|l|}{ Laser ablation (LA) } \\
\hline Model & Geolas 200 Q-Microlas \\
\hline Type & Excimer ArF \\
\hline Wavelength & $193 \mathrm{~nm}$ \\
\hline Repetion rate & $3 \mathrm{~Hz}$ \\
\hline Energy density & $12 \mathrm{~J} \mathrm{~cm}^{-2}$ \\
\hline Spot diameter & $10 \mathrm{~mm}$ \\
\hline Data acquisition & \\
\hline Determined isotopes & $\begin{array}{l}{ }^{202} \mathrm{Hg},{ }^{204}(\mathrm{~Pb}+\mathrm{Hg}),{ }^{206} \mathrm{~Pb},{ }^{208} \mathrm{~Pb},{ }^{232} \mathrm{Th},{ }^{238 \mathrm{U}}\end{array}$ \\
\hline Data reduction software & $\begin{array}{l}\text { GLITTER (van } \\
\quad \text { Achterbergh } \text { et al. 2001) }\end{array}$ \\
\hline
\end{tabular}

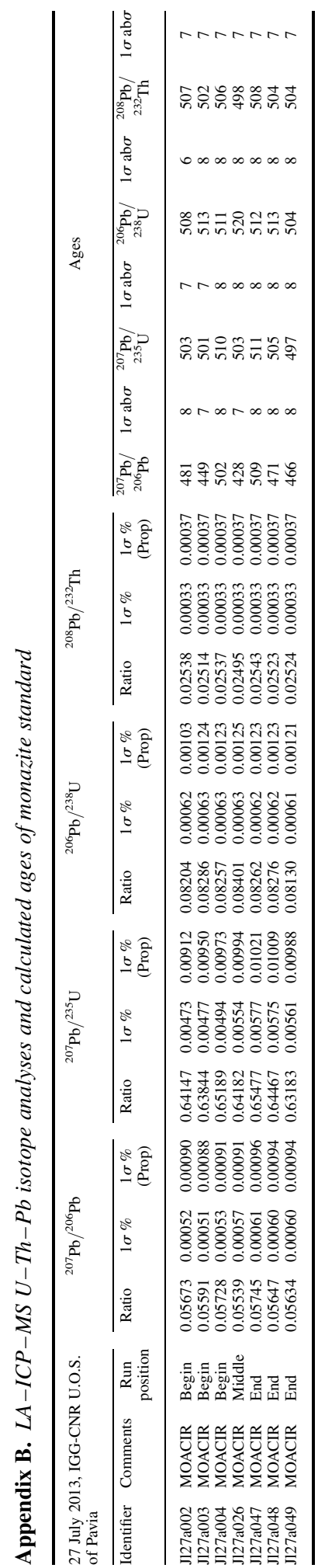




\section{R. CAROSI ET AL.}

\section{References}

Antolín, B., Appel, A., Montomoli, C., Dunkl, I., Ding, L., Gloaguen, R. \& El Bay, R. 2011. Kinematic evolution of the eastern Tethyan Himalaya: constraints from magnetic fabric and structural properties of the Triassic flysch in SE Tibet. In: POBLET, J. \& Lisle, R. (eds) Kinematic Evolution and Structural Styles of Fold-and-Thrust Belts. Geological Society, London, Special Publications, 349, 99-121.

Bartoli, O., Cesare, B., Poli, S., Bodnar, R. J., AcostaVigil, A., Frezzotti, M. L. \& Meli, S. 2013a. Recovering the composition of melt and the fluid regime at the onset of crustal anatexis and S-type granite formation. Geology, 41, 115-118.

Bartoli, O., Cesare, B. et al. 2013b. Nanogranite inclusions in migmatitic garnet: behavior during piston cylinder re-melting experiments. Geofluids, 13, 405-420.

Beaumont, C., Jamieson, R. A., Nguyen, M. H. \& Lee, B. 2001. Himalayan tectonics explained by extrusion of a low-viscosity crustal channel coupled to focused surface denudation. Nature, 414, 738-742.

BernhardT, H.-J. 2010. MINCALC-V5, a non EXCEL based computer program for general electron-microprobe mineral analyses data processing. IAM 20th General Meeting. Acta mineralogica-petrographica abstract series, 6, 869 .

Bordet, P. 1961. Recherches geologiques dans l'Himalaya du Nepal, region du Makalu. Centre National de la Recherche Scientifique, Paris.

Brown, R. L. \& Nazarchuk, J. H. 1993. Annapurna detachment fault in the Greater Himalaya of central Nepal. In: Treloar, P. J. \& Searle, M. P. (eds) Himalayan Tectonics. Geological Society, London, Special Publications, 74, 461-473.

Brunel, M. \& Kienast, J. R. 1986. Etude petro-structurale des chevauchements ductiles himalayens sur la transversale de l'Everest-Makalu (Nepal oriental). Canadian Journal of Earth Sciences, 23, 1117-1137.

Burchfiel, B. C., Chen, Z., Hodges, K. V., Liu, Y., Royden, L. H., Deng, C. \& Xu, L. 1992. The South Tibetan Detachment System, Himalayan Orogen: extension contemporaneous with and parallel to shortening in a collisional mountain belt. In: BURCHFIEL, B. C., Chen, Z., Hodges, K. V., Liu, Y., Royden, L. H., Deng, C. \& Xu, J. (eds) The South Tibetan Detachment System, Himalayan Orogen: Extension Contemporaneous With and Parallel to Shortening in a Collisional Mountain Belt. Geological Society of America Special Papers, 269, 1-41.

Carosi, R., Lombardo, B., Musumeci, G. \& Pertusati, P. C. 1999. Geology of Higher Himalayan in Khumbu Himal (Eastern Nepal). Journal of Asian Earth Sciences, 17, 785-803.

Carosi, R., Montomoli, C. \& Visonà, D. 2002. Is there any detachment in the Lower Dolpo (western Nepal)? Comptes Rendus Geoscience, 334, 933-940.

Carosi, R., Montomoli, C. \& Visonì, D. 2007. A structural transect in the Lower Dolpo: insights on the tectonic evolution of Western Nepal. Journal of Asian Earth Sciences, 29, 407-423.

Carosi, R., Montomoli, C., Rubatto, D. \& Visonà, D. 2010. Late Oligocene high-temperature shear zones in the core of the Higher Himalayan Crystalline (Lower Dolpo, Western Nepal). Tectonics, 29, TC4029, http://dx.doi.org/10.1029/2008TC002400

Carosi, R., Montomoli, C., Rubatto, D. \& Visonà, D. 2013. Leucogranite intruding the South Tibetan Detachment in western Nepal: implications for exhumation models in the Himalayas. Terra Nova, 25, 478-489, http://dx.doi.org/10.1111/ter.12062

Catlos, E., Harrison, T. M., Kohn, M. J., Grove, M., Lovera, O. M., Ryerson, F. J. \& Upreti, B. N. 2001. Geochronologic and thermobarometric constraints on the evolution of the Main Central Thrust, central Nepal Himalaya. Journal of Geophysical Research, 106, 16 177-16203.

Catlos, E. J., Harrison, T. M., Manning, C. E., Grove, M., Rai, S. M., HubBard, M. S. \& Upreti, B. N. 2002. Records of the evolution of the Himalayan orogen from in situ $\mathrm{Th}-\mathrm{Pb}$ ion microprobe dating of monazite: Eastern Nepal and western Garhwal. Journal of Asian Earth Sciences, 20, 459-479.

Catlos, E. J., Dubey, C. S., Marston, R. A. \& Harrison, T. M. 2007. Geochronologic constraints across the Main Central Thrust shear zone, Bhagirathi River (NW India): implications for Himalayan tectonics. In: Cloos, M., Carlson, W. D., Gilbert, M., Liou, J. G. \& Sorensen, S. S. (eds) Convergent Margin Terranes and Associated Regions: A Tribute to W.G. Ernst. Geological Society of America Special Papers, 419, 135-151.

Cesare, B., Ferrero, S., Salvioli-Mariani, E., Pedron, D. \& Cavallo, A. 2009. Nanogranite and glassy inclusions: the anatectic melt in migmatites and granulites. Geology, 37, 627-630.

Cesare, B., Acosta-Vigil, A., Ferrero, S. \& Bartoli, O. 2011. Melt inclusions in migmatites and granulites. Journal of the Virtual Explorer, 40, 2.

Colchen, M., PÊCher, A. \& LeFort, P. 1986. Recherches Geologiques dans l'Himalaya du Nepal: Annapurna-Manaslu-Ganesh Himal. Editions du Centre National de la Recherches Scientifique, Paris.

Coleman, M. E. 1998. U-Pb constraints on OligoceneMiocene deformation and anatexis within the Central Himalaya, Marsyandi valley, Nepal. American Journal of Science, 298, 553-571.

Corrie, S. L. \& KoHn, M. J. 2011. Metamorphic history of the Central Himalaya, Annapurna region, Nepal, and implication for tectonic models. Geological Society of America Bulletin, 123, 1863-1879.

Crouzet, C., Dunkl, I., Paudel, L., Arkai, P., Rainer, T. M., Balogh, K. \& ApPel, E. 2007. Temperature and age constraints on the metamorphism of the Tethyan Himalaya in Central Nepal: a multidisciplinary approach. Journal of Asian Earth Sciences, 30, $113-130$.

Cruz, M. J., Cunha, J. C., Merlet, C. \& Sabaté, P. 1996. Dataçao pontual das monazitas da regiao de Itambe, Bahia, através da microssonda eletrônica. XXXIX Congresso Brasileiro de Geologia, Sociedade Brasileira de Geologià-Núcleo, Bahià-Segipe, 2, 206-209.

DeCelles, P. G., Gehrels, G. E., Quade, J., Ojha, T. P., KAPP, P. A. \& Upreti, B. N. 1998. Neogene foreland basin deposits, erosional unroofing, and the kinematic history of the Himalayan fold-thrust belt, western 
Nepal. Geological Society of America Bulletin, 110, $2-21$.

Dumond, G., McLean, N., Williams, M. L., Jercinovic, M. J. \& Bowring, S. A. 2008. High resolution dating of granite petrogenesis and deformation in a lower crustal shear zone: Athabasca granulite terrane, western Canadian Shield. Chemical Geology, 254, $175-196$.

Dunkl, I., Antolín, B. ET AL. 2011. Metamorphic evolution of the Tethyan Himalayan flysch in SE Tibet. In: Gloaguen, R. \& Ratschbacher, L. (eds) Growth and Collapse of the Tibetan Plateau. Geological Society, London, Special Publications, 353, 45-69.

FERrero, S., Bartoli, O. ET AL. 2012. Microstructures of melt inclusions in anatectic metasedimentary rocks. Journal of Metamorphic Geology, 30, 303-322.

Ferri, F., Poli, S. \& Vielzeuf, D. 2009. An experimental determination of the effect of bulk composition on phase relationships in metasediments at near-solidus conditions. Journal of Petrology, 50, 909-93.

Foster, G. \& PARRISH, R. R. 2003. Metamorphic monazite and generation of $\mathrm{P}-\mathrm{T}-\mathrm{t}$ paths. In: VANCE, D., Müller, W. \& Villa, I. M. (eds) Geochronology: Linking the Isotopic Record with Petrology and Textures. Geological Society, London, Special Publications, 220, 25-47.

Foster, G., Kinny, P., Vance, D., Prince, C. \& Harris, N. 2000. The significance of monazite $\mathrm{U}-\mathrm{Th}-\mathrm{Pb}$ age data in metamorphic assemblages; a combined study of monazite and garnet chronometry. Earth and Planetary Science Letters, 181, 327-340.

Gaetani, M. \& Garzanti, E. 1991. Multicyclic history of the northern India continental margin (Northwestern Himalaya). American Association of Petroleum Geologists Bulletin, 75, 1427-1446.

GANSSER, A. 1964. Geology of the Himalayas. Wiley Interscience, London.

Gansser, A. 1983. Geology of the Bhutan Himalaya. Basel, Birkhäuser Verlag.

García-Casco, A., Haissen, F., Castro, A., El-Hmidi, H., Torres-Roldìn, R. L. \& Millàn, G. 2003. Synthesis of staurolite in melting experiments of a natural metapelite: consequences for phase relations in low-temperature pelitic migmatites. Journal of Petrology, 44, 1727-1757.

Gasquet, D., Bertrand, J. M. et al. 2010. Miocene to Messinian deformation and hydrothermal activity in a pre-Alpine basement massif of the French western Alps: new $\mathrm{U}-\mathrm{Th}-\mathrm{Pb}$ and argon ages from the Lauzière massif. Bulletin de la Société Géologique de France, 181, 227-241.

Gibson, H. D., Carr, S. D., Brown, R. L. \& Hamilton, M. 2004. Correlations between chemical and age domains in monazite, and metamorphic reactions involving major pelitic phases: an integration of IDTIMS and SHRIMP geochronology with Y-Th-U X-ray mapping. Chemical Geology, 211, 237-260.

GoDIN, L. 2003. Structural evolution of the Tethyan sedimentary sequence in the Annapurna area, central Nepal Himalaya. Journal of Asian Earth Sciences, 22, 307-328.

Godin, L., Parrish, R. R., Brown, R. L. \& Hodges, K. V. 2001. Crustal thickening leading to exhumation of the
Himalayan metamorphic core of central Nepal: insight from $\mathrm{U}-\mathrm{Pb}$ geochronology and $40 \mathrm{Ar} / 39 \mathrm{Ar}$ thermochronology. Tectonics, 20, 729-747.

Godin, L., Grujic, D., Law, R. D. \& Searle, M. P. 2006. Channel flow, ductile extrusion and exhumation in continental collision zones: an introduction. In: LAW, R. D., Searle, M. P. \& Godin, L. (eds) Channel Flow, Ductile Extrusion and Exhumation in Continental Collision Zones. Geological Society, London, Special Publications, 268, 1-23.

Goscombe, B., Gray, D. \& Hand, M. 2006. Crustal architecture of the Himalayan metamorphic front in eastern Nepal. Gondwana Research, 10, 232-255.

Groppo, C., Rubatto, D., Rolfo, F. \& Lombardo, B 2010. Early Oligocene partial melting in Main Central Thrust Zone (Arun valley, eastern Nepal Himalaya). Lithos, 118, 287-301.

Groppo, C., Rolfo, F. \& Indares, A. 2012. Partial Melting in the Higher Himalayan Crystallines of Eastern Nepal: the effect of decompression and implications for the 'Channel Flow' Model. Journal of Petrology, 53, 1057-1088.

Guilmette, C., Indares, A. \& Hebert, R. 2010. Highpressure anatectic metapelites from the Namche Barwa, Eastern Himalayan Syntaxis: textural evidence for partial melting, phase equilibria modelling and tectonic implications. Lithos, 124, 66-81.

Harris, N. \& Massey, J. 1994. Decompression and anatexis of Himalayan metapelites. Tectonics, 13, $1537-1546$.

Hiess, J., Condon, D. J., Mclean, N. \& Noble, S. R. 2012. ${ }^{238} \mathrm{U} /{ }^{235} \mathrm{U}$ systematics in terrestrial Uraniumbearing minerals. Geology, 335, 1610-1614.

Hodges, K. V. 2000. Tectonics of the Himalaya and southern Tibet from two perspectives. Geological Society of America Bulletin, 112, 324-350.

Hodges, K. V., Parrish, R. R. \& Searle, M. P. 1996. Tectonics evolutions of the Central Annapurna Range Nepalese Himalayas. Tectonics, 15, 1264-1291.

Holness, M., Cesare, B. \& Sawyer, E. W. 2011. Melted rocks under the microscope: microstructures and their interpretation. Elements, 7, 247-252.

Horstwood, M. S. A., Foster, G. L., Parrish, R. R., Noble, S. R. \& Nowell, G. M. 2003. Common-Pb corrected in situ $\mathrm{U}-\mathrm{Pb}$ accessory mineral geochronology by LA-MCICP-MS. Journal of Analytical Atomic Spectrometry, 18, 837-846, http://dx.doi.org/10. $1039 / \mathrm{b} 304365 \mathrm{~g}$

Imayama, T., TAKeshite, T. $\quad E T$ AL. 2012. Twostage partial melting and contrasting cooling history within the Higher Himalayan Crystalline sequence in the far-eastern Nepal Himalaya. Lithos, 134-135, $1-22$.

Kellett, D. A. \& Godin, L. 2009. Pre-Miocene deformation of the Himalayan superstructure, Hidden valley, central Nepal. Journal of the Geological Society, London, 166, 261-275.

Kenkmann, T. \& Dresen, G. 1998. Stress gradients around porphyroclasts: palaeo-piezo-metric estimates and numerical modelling. Journal of Structural Geology, 20, 163-173.

King, J., Harris, N., Argles, T., Parrish, R. \& Zhang, H. 2011. Contribution of crustal anatexis to the tectonic evolution of Indian crust beneath southern 


\section{R. CAROSI ET AL.}

Tibet. Geological Society of America Bulletin, 123, 218-239.

Kohn, M. J. \& Spear, F. S. 2000. Retrogade net transfer reaction insurance for pressure-temperature estimates. Geology, 29, 1127-1130.

Kohn, M. J., Wieland, M. S., Parkinson, C. D. \& Upreti, B. N. 2004. Miocene faulting at plate tectonic velocity in the Himalaya of central Nepal. Earth and Planetary Science Letters, 228, 299-310.

Kohn, M. J., Wieland, M. S., Parkinson, C. D. \& Upreti, B. N. 2005. Five generations of monazite in Langtang gneisses: implications for chronology of the Himalayan metamorphic core. Journal of Metamorphic Geology, 23, 399-406.

Langone, A., Braga, R., Massonne, H.-J. \& Tiepolo, M. 2011. Preservation of old (prograde metamorphic) $\mathrm{U}-\mathrm{Th}-\mathrm{Pb}$ ages in unshielded monazite from the highpressure paragneisses of the Variscan Ulten Zone (Italy). Lithos, 127, 68-85.

Larson, K. P., Godin, L. \& Price, R. A. 2010. Relationships between displacement and distortion in orogens: linking the Himalayan foreland and hinterland in central Nepal. Geological Society of America Bulletin, 122, 1116-1134.

Larson, K. P., Gervais, F. \& Kellett, D. A. 2013. A $\mathrm{P}-\mathrm{T}-\mathrm{t}-\mathrm{D}$ discontinuity in east-central Nepal: implications for the evolution of the Himalayan midcrust. Lithos, 179, 275-292.

LE FORT, P. 1975. Himalayas: the Collided Range. Present Knowledge of the Continental Arc. American Journal of Science, 275, 1-44.

Lombardo, B., Pertusati, P. \& Borghi, A. 1993. Geology and tectono-magmatic evolution of the eastern Himalaya along the Chomolungma-Makalu transect. In: Treloar, P. J. \& Searle, M. P. (eds) Himalayan Tectonics. Geological Society, London, Special Publications, 74, 341-355.

LudWIG, K. R. 2003. Isoplot/Ex version 3.0. A geochronological toolkit for Microsoft Excel. Berkeley Geochronology Center, Special Publications, 4.

Martin, A. J., Gehrels, G. E. \& DeCelles, P. G. 2007. The tectonic significance of $(\mathrm{U}, \mathrm{Th}) / \mathrm{Pb}$ ages of monazite inclusions in garnet from the Himalaya of central Nepal. Chemical Geology, 244, 1-24.

Montel, J. M., Kornprobst, J. \& Vielzeuf, D. 2000. Preservation of old $\mathrm{U}-\mathrm{Th}-\mathrm{Pb}$ ages in shielded monazite; example from the Beni Bousera Hercynian kinzigites (Morocco). Journal of Metamorphic Geology, 18, 335-342.

Montomoli, C., Iaccarino, S., Carosi, R., Langone, A. \& VISONÀ, D. 2013. Tectonometamorphic discontinuities within the Greater Himalayan Sequence in Western Nepal (Central Himalaya): insights on the exhumation of crystalline rocks. Tectonophysics, $\mathbf{6 0 8}$ 1349-1370.

Montomoli, C., Carosi, R. \& Iaccarino, S. 2014. Tectonometamorphic discontinuities in the Greater Himalayan Sequence: a local or a regional feature? In: Mukherjee, S., Carosi, R., Van DeR BeeK, P. A., Mukherjee, B. K. \& Robinson, D M. (eds) Tectonics of the Himalaya. Geological Society, London, Special Publications, 412. First published online September 18, 2014, http://dx.doi.org/10. $1144 /$ SP412.3
MukherJeE, S. 2013. Channel flow extrusion model to constrain dynamic viscosity and Prandtl number of the Higher Himalayan Shear Zone. International Journal of Earth Sciences, 102, 1811-1835.

MukHERJEe, S. In prep. A review of an out-of-sequence deformation in the Himalaya. In: MukherJeE, S., Carosi, R., van der Beek, P. A., Mukherjee, B. K. \& Robinson, D. M. (eds) Tectonics of the Himalaya. Geological Society, London, Special Publications, 412.

MukherJee, S. \& Koyi, H. A. 2010a. Higher Himalayan Shear Zone, Sutlej section: structural geology and extrusion mechanism by various combinations of simple shear, pure shear and channel flow in shifting modes. International Journal of Earth Sciences, 99 , 1267-1303.

MukherJee, S. \& Koyi, H. A. 2010b. Higher Himalayan Shear Zone, Zanskar Indian Himalaya - microstructural studies \& extrusion mechanism by a combination of simple shear \& channel flow. International Journal of Earth Sciences, 99, 1083-1110.

Mukherjee, S., Koyi, H. A. \& Talbot, C. J. 2012. Implications of channel flow analogue models for extrusion of the Higher Himalayan Shear Zone with special reference to the out-of-sequence thrusting. International Journal of Earth Sciences, 101, 253-272.

PARrISH, R. R. 1990. U-Pb dating of monazite and its applications to geological problems. Canadian Journal of Earth Sciences, 27, 1431-1450.

Paquette, J. L. \& Tiepolo, M. 2007. High resolution $(5 \mu \mathrm{m}) \mathrm{U}-\mathrm{Th}-\mathrm{Pb}$ isotope dating of monazite with excimer laser ablation (ELA)-ICPMS. Chemical Geology, 240, 222-237.

Passchier, C. W. \& Trouw, R. J. 2005. Microtectonics. Springer Verlag, Berlin, Heidelberg.

PatiÑo-Douce, A. \& Harris, N. 1998. Experimental constraints on Himalayan anatexis. Journal of Petrology, 39, 689-710.

Pognante, U. \& Benna, P. 1993. Metamorphic zonation, migmatization, and leucogranites along the Everest transect (Eastern Nepal and Tibet): record of an exhumation history. In: Treloar, P. J. \& Searle, M. P. (eds) Himalayan Tectonics. Geological Society, London, Special Publications, 74, 323-340.

Prince, C. P., Harris, N. \& Vance, D. 2001. Fluid enhanced melting during prograde metamorphism. Journal of the Geological Society, London, 158, $233-241$.

Rubatto, D., Chakraborty, S. \& Dasgupta, S. 2012. Timescale of crustal melting in the Higher Himalayan Crystallines (Sikkim, Eastern Himalaya) inferred from trace element-constrained monazite and zircon chronology. Contributions to Mineralogy and Petrology, 165, 349-372.

SCHÄRER, U. 1984. The effect of initial ${ }^{230}$ Th disequilibrium on young $\mathrm{U}-\mathrm{Pb}$ ages: the Makalu case, Himalaya. Earth and Planetary Science Letters, 67, 191-204.

Schelling, D. 1992. The tectonostratigraphy and structure of the eastern Nepal Himalaya. Tectonics, 11, 925-943.

Searle, M. P. 2010. Low-angle normal faults in the compressional Himalayan orogen; Evidence from the Annapurna-Dhaulagiri Himalaya, Nepal. Geosphere, 6, 296-315. 
Searle, M. P. 2013. Crustal melting, ductile flow and deformation in mountain belts: cause and effect relationships. Lithosphere, 5, 547-554.

Searle, M. P. \& Godin, L. 2003. The South Tibetan detachment and the Manaslu leucogranite: a structural reinterpretation and restoration of the Annapurna Manaslu Himalaya, Nepal. Journal of Geology, 111, $505-523$.

Searle, M. P. \& Szluc, A. G. 2005. Channel flow and ductile extrusion of the High Himalayan slab, Kangchenjungs-Darjeeling profile, Sikkim Himalaya. Journal of Asian Earth Sciences, 25, 173-185.

Seydoux-Guillaume, A. M., Paquette, J. L., WiedenBeck, M., Montel, J. M. \& Heinrich, W. $2002 a$. Experimental resetting of the $\mathrm{U}-\mathrm{Th}-\mathrm{Pb}$ system in monazite. Chemical Geology, 191, 165-181.

Seydoux-Guillaume, A. M., Wirth, R., Nasdala, L., Gottschalk, M., Montel, J. M. \& Heinrich, W. 2002b. XRD, TEM and Raman study of experimental annealing of natural monazite. Physics and Chemistry of Minerals, 29, 240-253.

Simpson, R. L., Parrish, R. R., Searle, M. P.\& Waters, D. J. 2000. Two episodes of monazite crystallisation during metamorphism and crustal melting in the Everest region of the Nepalese Himalaya. Geology, 28, 403-406.

SPEAR, F. S. 2010. Monazite-allanite phase relations in metapelites. Chemical Geology, 279, 55-62.

Spear, F. S. \& Pyle, J. M. 2002. Apatite, monazite, and xenotime in metamorphic rocks. Reviews in Mineralogy and Geochemistry, 48, 293-335.

SPEAR, F. S. \& PyLE, J. M. 2010. Theoretical modeling of monazite growth in a low-Ca metapelite. Chemical Geology, 273, 111-119.

Streule, M. J., Searle, M. P., Waters, D. J. \& HorstwooD, M. S. A. 2010. Metamorphism, melting and channel flow in the Greater Himalaya Sequence and Makalu leucogranite: constraints from thermobarometry, metamorphic modelling and $\mathrm{U}-\mathrm{Pb}$ geochronology. Tectonics, 29, TC5011, http://dx.doi.org/10. 1029/2009TC002533

Szulc, A. G., NaJman, Y. et AL. 2006. Tectonic evolution of the Himalaya constrained by detrital ${ }^{40} \mathrm{Ar}-{ }^{39} \mathrm{Ar}$, $\mathrm{Sm}-\mathrm{Nd}$ and petrographic data from the Siwalik foreland basin succession, SW Nepal. Basin Research, 18, 375-391.

Tiepolo, M., Bottazzi, P., Palenzona, M. \& Vannucci, R. 2003. A laser probe coupled with ICP - DoubleFocusing Sector-Field mass spectrometer from in situ analysis of geological samples and $\mathrm{U}-\mathrm{Pb}$ dating of zircon. The Canadian Mineralogist, 41, 259-272.

Tobgay, T., McQuarrie, N., Long, S., Kohn, M. J. \& Corrie, S. L. 2012. The age and rate of displacement along the Main Central Thrust in the western Bhutan Himalaya. Earth and Planetary Science Letters, 319-320, 146-158.

Upreti, B. N. 1999. An overview of the stratigraphy and tectonics of the Nepal Himalaya. Journal of Asian Earth Sciences, 17, 577-606.

Upreti, B. N. \& YoshidA, M. 2005. Guidebook for Himalayan Trekkers; Geology and Natural Hazards along the Kaligandaki Valley, Nepal. Department of Geology Tri-Chandra Campus, Tribhuvan University, Kathmandu, Nepal.

van Achterbergh, E., Ryan, C. G., Jackson, S. E. \& GRIFFIN, W. 2001. Data reduction software for LA-ICPMS. In: Sylvester, P. (ed.) Laser ablation ICPMS in the Earth sciences: Principles and Applications. Mineralogical Association of Canada Short Course Series, 29, 239-243.

VANCE, D. \& Harris, N. B. W. 1999. The timing of early decompression in the Himalaya: implications for crustal melting. Geology, 27, 395-398.

Vannay, J. C. \& Hodges, K. V. 1996. Tectonometamorphic evolution of the Himalayan metamorphic core between the Annapurna and Dhaulaghiri, Central Nepal. Journal of Metamorphic Geology, 14, 635-656.

VERNON, R. H. 2011. Microstructures of melt-bearing regional metamorphic rocks. In: VAN REENEN, D. D., Kramers, J. D., McCourt, S. \& Perchuk, L. L. (eds) Origin and Evolution of Precambrian HighGrade Gneiss Terranes, with Special Emphasis on the Limpopo Complex of Southern Africa. Geological Society of America, Memoirs, 207, 1-11.

Visonà, D. \& Lombardo, B. 2002. Two-mica and tourmaline leucogranites from Everest-Makalu region (Nepal-Tibet). Himalayan leucogranites genesis by isobathic heating? Lithos, 62, 125-150.

Visonà, D., Carosi, R., Montomoli, C., Peruzzo, L. \& TiePolo, M. 2012. Miocene andalusite leucogranite in central-east Himalaya (Everest-Masang Kang area): low-pressure melting during heating. Lithos, 144, 194-208.

White, N. M., Pringle, M., Garzanti, E., Bickle, M., Najman, Y., Chapman, H. \& Friend, P. 2002. Constraints on the exhumation and erosion of the High Himalayan Slab, NW India, from foreland basin deposits. Earth Sciences Reviews, 195, 29-44.

Whitney, D. J. \& Evans, B. W. 2010. Abbreviations for names of rock-forming minerals. American Mineralogist, 95, 185-187.

Williams, M. L. \& Jercinovic, M. J. 2002. Microprobe monazite geochronology: putting absolute time into microstructural analysis. Journal of Structural Geology, 24, 1013-1028.

Williams, M. L. \& Jercinovic, M. J. 2012. Tectonic interpretation of metamorphic tectonites: integrating compositional mapping, microstructural analysis and in situ monazite dating. Journal of Metamorphic Geology, 30, 739-752.

YIN, A. 2006. Cenozoic tectonic evolution of the Himalaya orogen as constrained by along-strike variation of structural geometry, exhumation history, and foreland sedimentation. Earth Sciences Reviews, $\mathbf{7 6}$ $1-132$.

Zeng, L., GaO, Li-E., Dong, C. \& TANG, S. 2012. Highpressure melting of metapelite and the formation of Ca-rich granitic melts in the Namche Barwa Massif, southern Tibet. Gondwana Research, 21, $138-151$ 